Supporting Information

for

\title{
A Sterically Congested Nitrogenated Benzodipentaphene with a Double ח-Expanded Helicene Structure
}

\author{
Fengkun Chen, ${ }^{[a]}$ Wenting Gu, ${ }^{[b]}$ Akinori Saeki, $\left.{ }^{b}\right]$ Manuel Melle-Franco, ${ }^{[c]}$ and Aurelio \\ Mateo-Alonso*[a][d] \\ aPOLYMAT, University of the Basque Country UPV/EHU. Avenida de Tolosa 72, 20018 Donostia-San Sebastian \\ (Spain) \\ bDepartment of Applied Chemistry, Graduate School of Engineering, Osaka University, Suita, Osaka 565-0871 \\ (Japan) \\ cCICECO - Aveiro Institute of Materials. Department of Chemistry, University of Aveiro. 3810-193 Aveiro \\ (Portugal) \\ dIkerbasque, Basque Foundation for Science, Bilbao (Spain)
}


a)

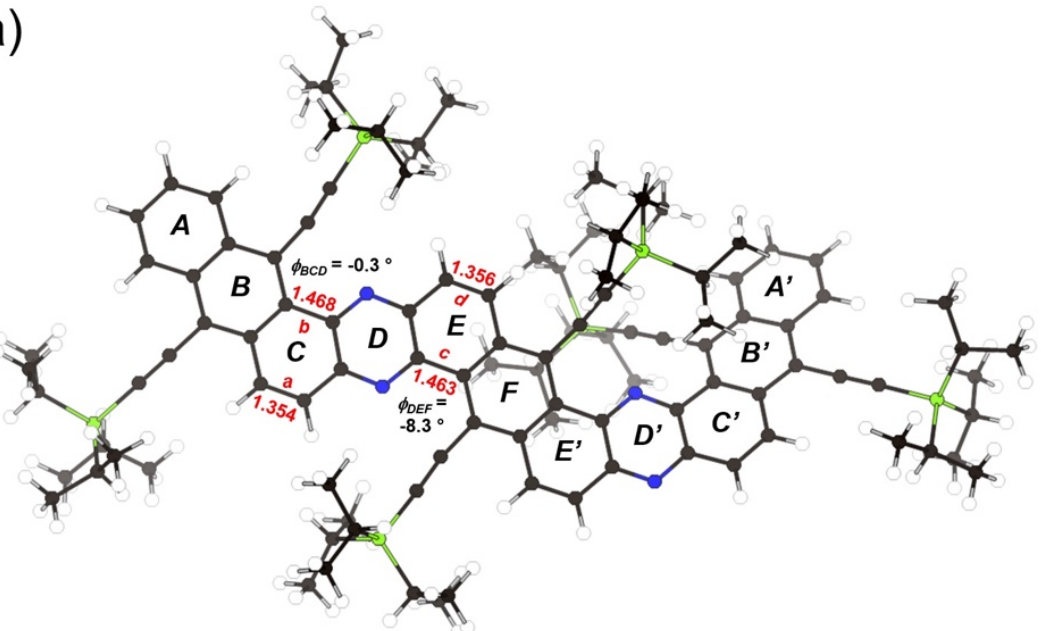

b)

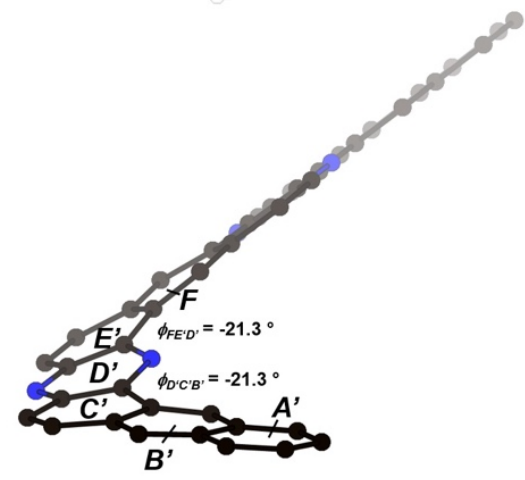

Figure S1. a) Top and b) side views of the DFT optimised geometry of 2 with selected bond lengths (in $\AA$ ) and selected torsion angles. Triisopropylsilylethynyl substituents and hydrogen atoms are omitted for clarity in the side view. 


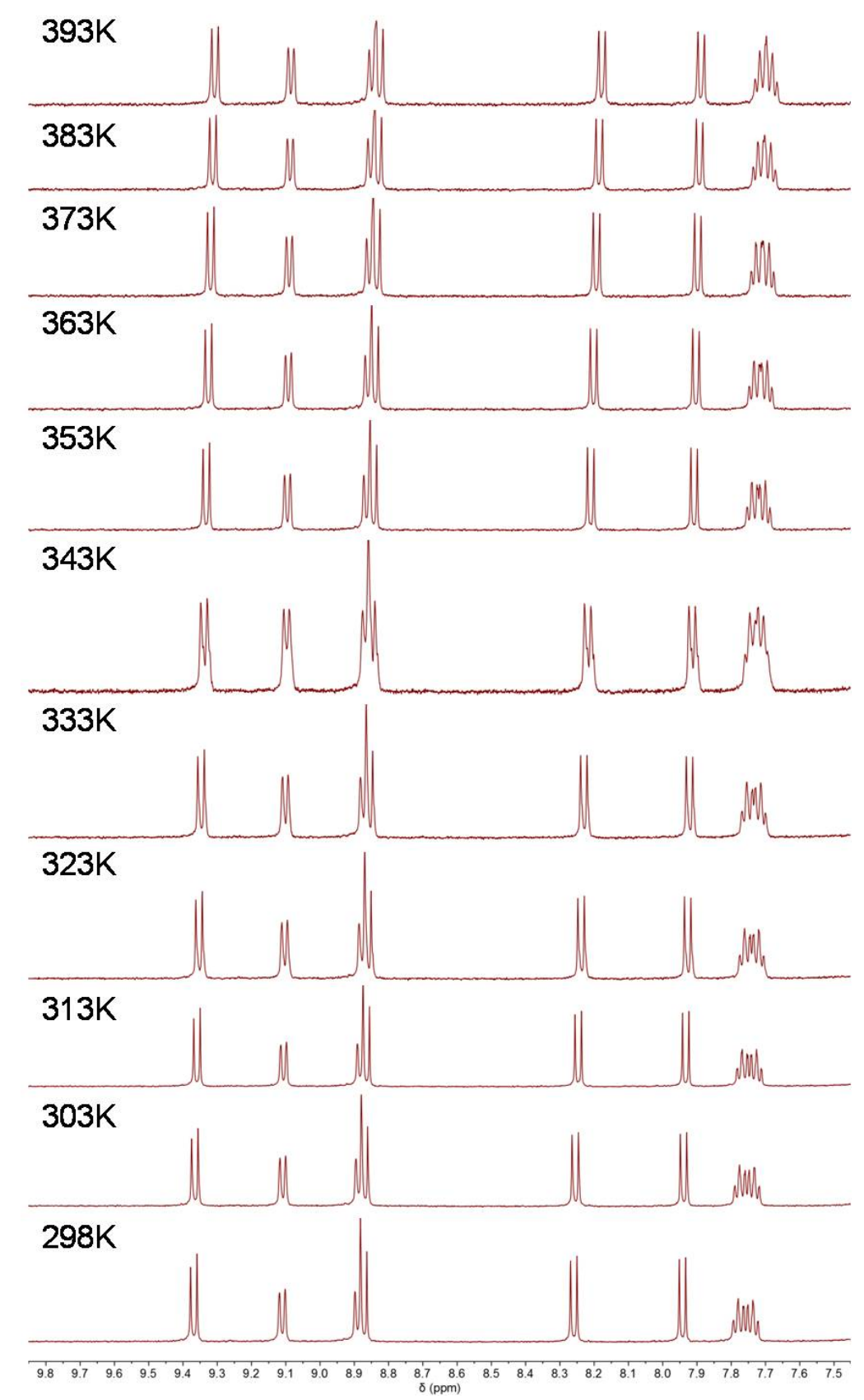

Figure S2. Partial ${ }^{1} \mathrm{H}$ NMR spectrum of 3 in $o$-dichlorobenzene- $d 4$ at different temperatures (500 MHz). 

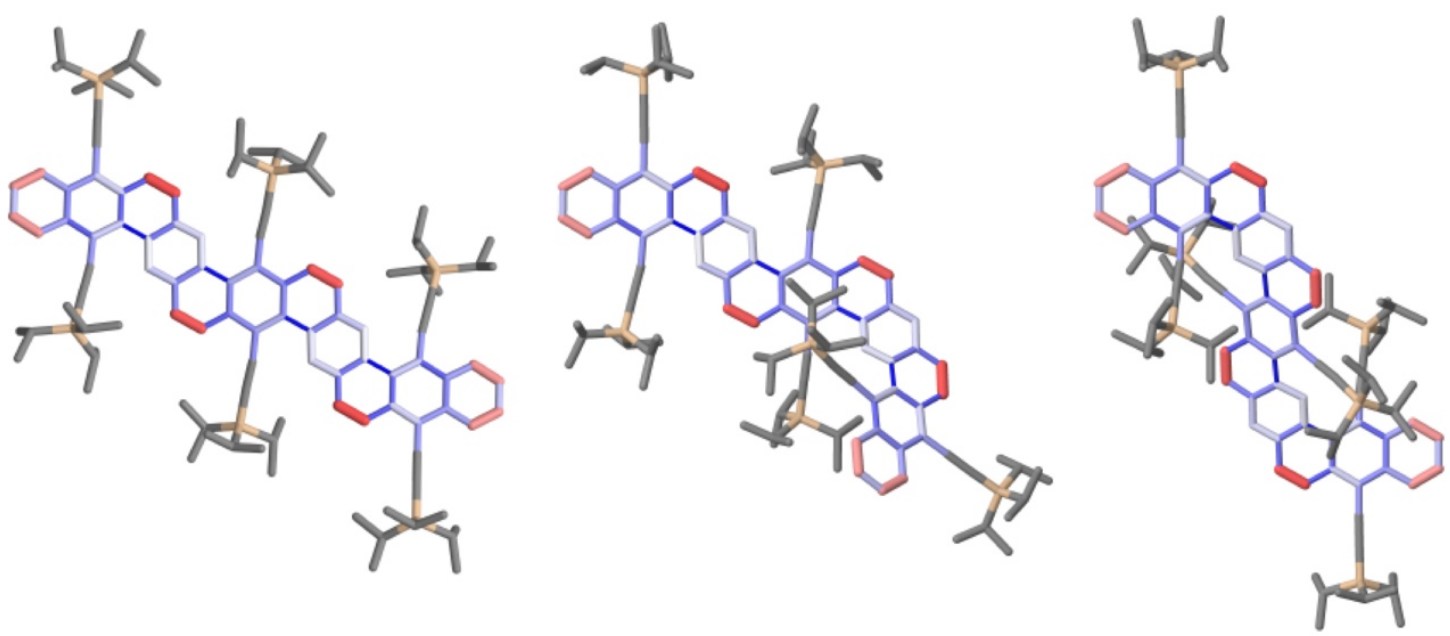

Figure S3. Csp ${ }^{2}-\mathrm{Csp}^{2}$ bond alternation for the lowest energy structures at the B3LYP-6-31g(d,p) level of 1-3 from left to right, in vacuum coloured by a scheme that highlights the bond alternation (for details see table above). Bonds are rendered in a colour continuum ranging from red $(1.33 \mathrm{~A})$ to white $(1.40 \mathrm{~A})$ to blue $(1.47 \mathrm{~A})$ so that Clar's aromatic sextets are lighter/whiter colours and localized double and single bonds are red and blue, respectively. 


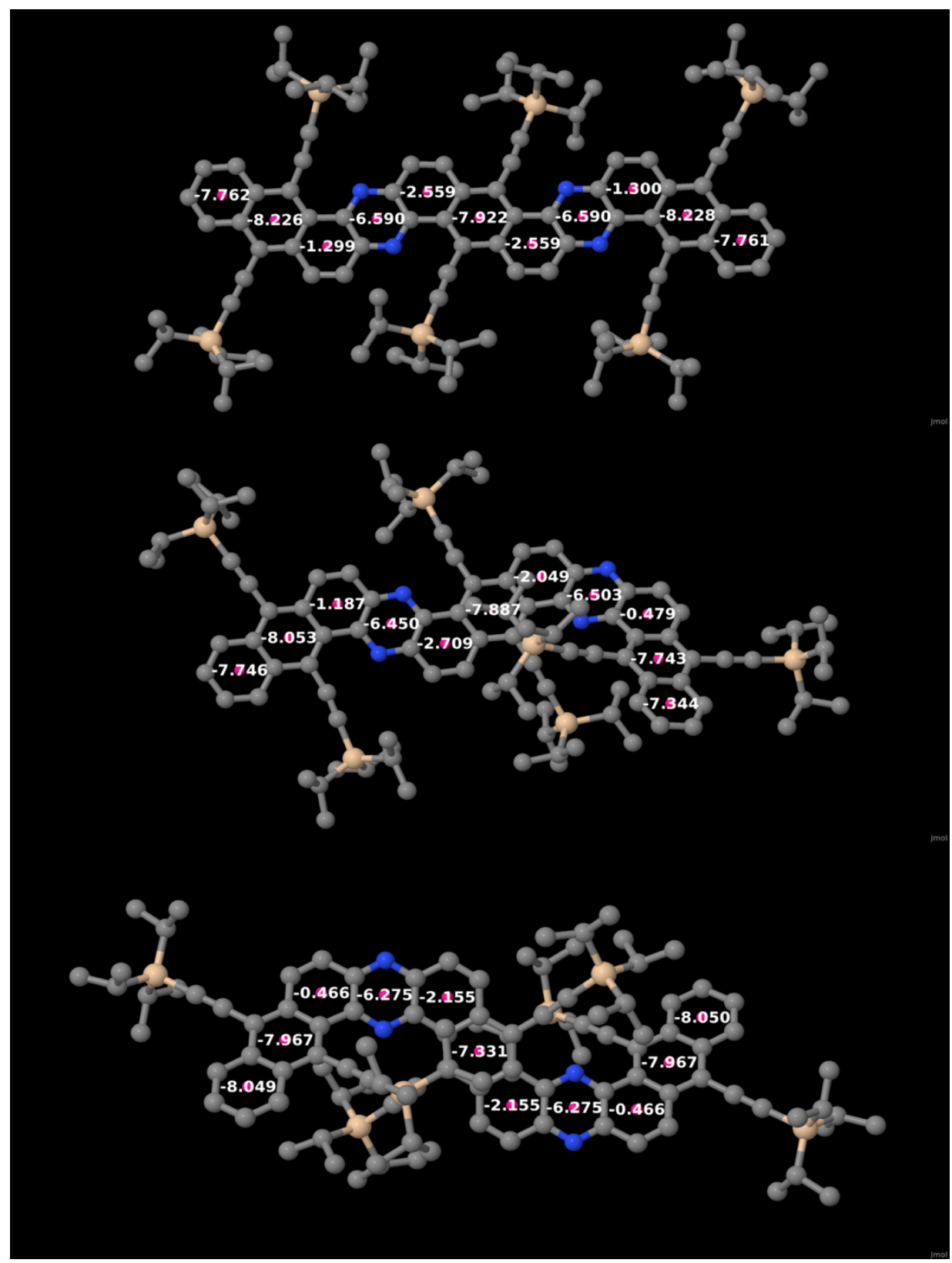

Figure S4. NICS(0) values calculated at the the B3LYP-6-311+g(2d,p)/B3LYP-6-31g(d,p) level for 1 (top), $\mathbf{2}$ (center) and $\mathbf{3}$ (bottom). 

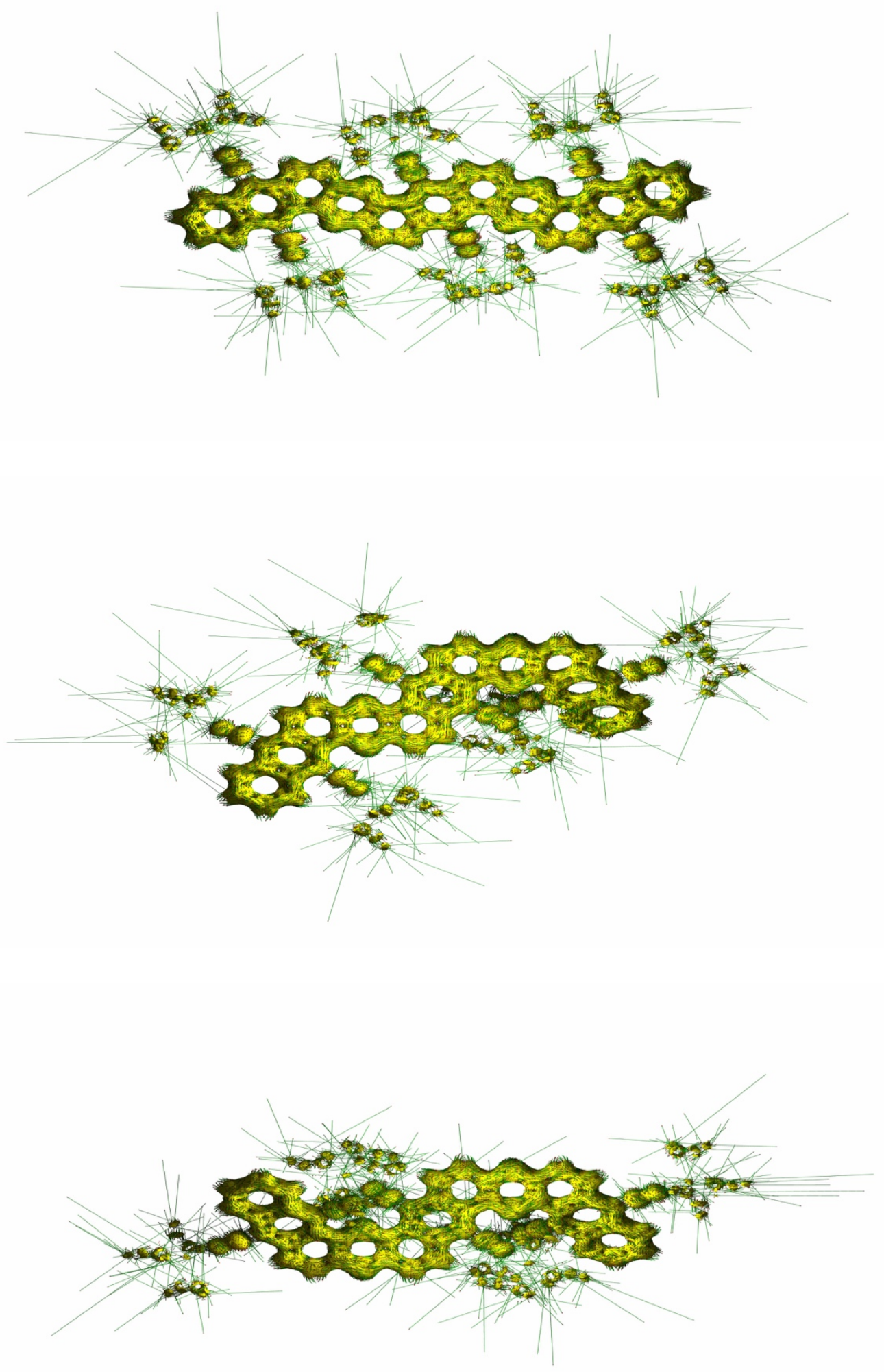

Figure S5. ACID values calculated at the the the B3LYP-6-31g(d,p) level for 1 (top), 2 (center) and 3 (bottom). 

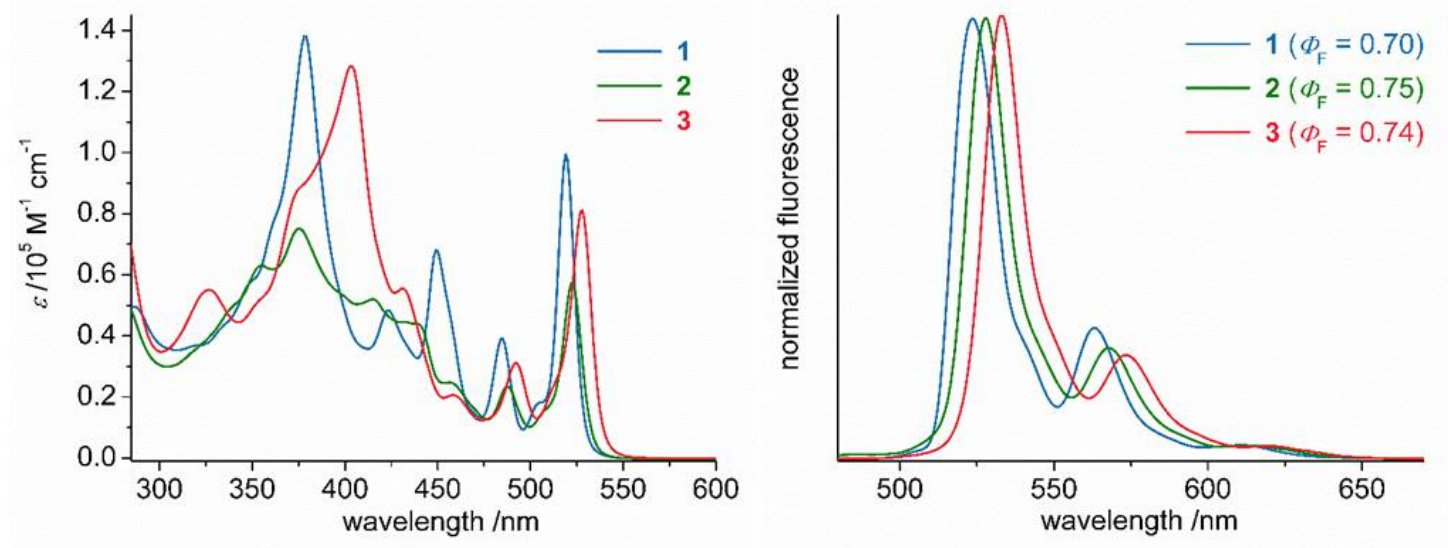

Figure S6. a) UV/Vis absorption and b) fluorescence spectra in toluene. 


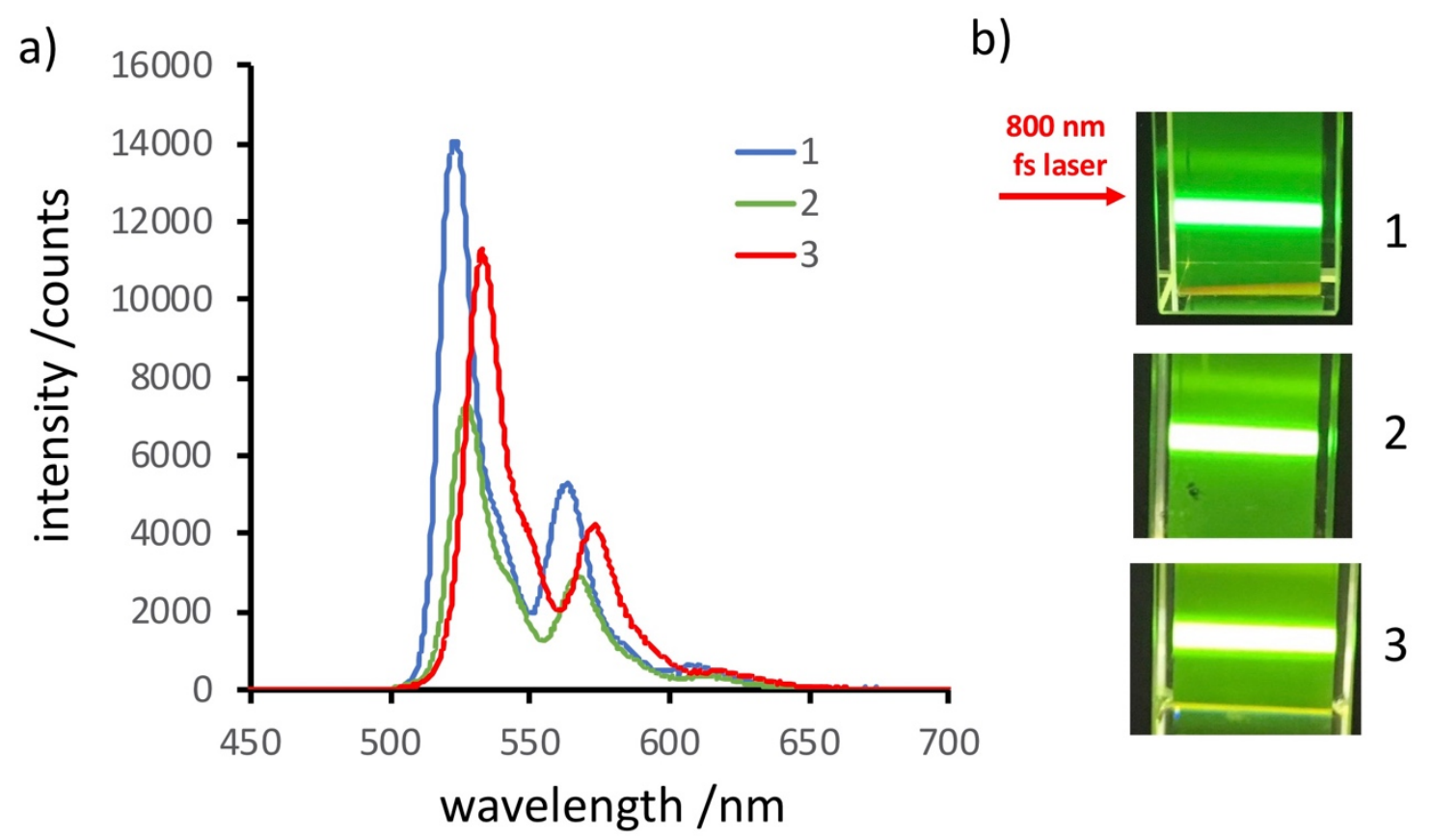

Figure S7. (a) Fluorescence spectra of benzodipentaphenes 1-3 induced by TPA using $800 \mathrm{~nm}$ femtosecond laser at $9.6 \mathrm{~mJ} / \mathrm{cm}^{2}$. b) Still pictures of TPA experiments. The laser is exposed from the right side. 


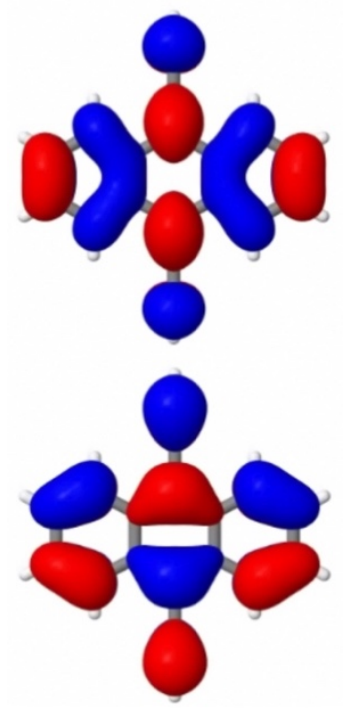

Figure S8. LUMO (top) and HOMO (bottom) Orbitals at the B3LYP-6-31g(d,p) level for 9,10-bis(ethynyl)anthracene. 
Table S1. Selected optoelectronic properties.

\begin{tabular}{|c|c|c|c|c|c|c|c|c|c|c|}
\hline \multirow[b]{2}{*}{ cmp. } & \multicolumn{5}{|c|}{ DCM } & \multicolumn{5}{|c|}{ Toluene } \\
\hline & $\begin{array}{c}\lambda_{a \mathrm{bs},} \\
\max \\
(\mathrm{nm})\end{array}$ & $\begin{array}{c}\lambda_{a \mathrm{bs},} \\
\text { onset } \\
(\mathrm{nm})\end{array}$ & $\begin{array}{c}E_{g} \\
{ }_{\text {opt }}^{a} \\
(\mathrm{eV})\end{array}$ & $\begin{array}{l}\lambda_{e m}, \\
\max ^{\mathrm{b}} \\
(\mathrm{nm})\end{array}$ & $\Phi_{\mathrm{F}}^{c}$ & $\begin{array}{c}\lambda_{a b s,} \\
\max \\
(\mathrm{nm})\end{array}$ & $\begin{array}{l}\lambda_{a b s,} \\
\text { onset } \\
(\mathrm{nm})\end{array}$ & $\begin{array}{c}E_{g} \\
{ }_{o p t}{ }^{a} \\
(\mathrm{eV})\end{array}$ & $\begin{array}{l}\lambda_{e m,} \\
\max ^{b} \\
(\mathrm{~nm})\end{array}$ & $\Phi_{\mathrm{F}}{ }^{c}$ \\
\hline 1 & 523 & 536 & 2.31 & 530 & 0.69 & 519 & 529 & 2.34 & 523 & 0.70 \\
\hline 2 & 526 & 542 & 2.29 & 534 & 0.70 & 523 & 534 & 2.32 & 528 & 0.75 \\
\hline 3 & 531 & 546 & 2.27 & 539 & 0.73 & 528 & 539 & 2.30 & 533 & 0.74 \\
\hline
\end{tabular}

${ }^{a}$ Optical band gap calculated with the onset wavelength of one-photon absorption spectrum in DCM using Planck-Einstein relation in $\mathrm{eV} .{ }^{b} \lambda_{\max }$ of one-photon fluorescence spectra in DCM in $\mathrm{nm}\left(\lambda_{\mathrm{ex}}=450 \mathrm{~nm}\right) .{ }^{c}$ Related fluorescence quantum yield in DCM with Rhodamine $6 \mathrm{G}$ in ethanol as standard (0.95). 
Table S2. First transition computed at the TD-B3LYP-CH${ }_{2} \mathrm{Cl}_{2}-6-311+\mathrm{g}(2 \mathrm{~d}, \mathrm{p}) / \mathrm{B} 3 \mathrm{LYP}-6-31 \mathrm{~g}(\mathrm{~d}, \mathrm{p})$ level. MD: molecular dynamics

\begin{tabular}{|c|c|c|c|c|c|c|c|}
\hline System & $\mathrm{eV}$ & $\mathrm{nm}$ & $\begin{array}{c}\text { Osc. } \\
\text { Strength }\end{array}$ & \multicolumn{4}{|c|}{ Contributions } \\
\hline $\mathbf{1}$ (crystal) & 2.24 & 553 & 0.62 & HOMO->LUMO & $73 \%$ & HOMO->L+1 & $23 \%$ \\
\hline $\mathbf{2}$ (MD) & 2.23 & 555 & 0.56 & HOMO->LUMO & $53 \%$ & HOMO->L+1 & $41 \%$ \\
\hline $\mathbf{3}$ (crystal) & 2.21 & 560 & 0.64 & HOMO->L +1 & $93 \%$ & H- $1->$ L +4 & $2 \%$ \\
\hline
\end{tabular}


Table S3. Selected electrochemical properties. Cyclic voltammograms in $o$-dichlorobenzene using $n \mathrm{Bu}_{4} \mathrm{NPF}_{6}(0.05 \mathrm{M})$ as an electrolyte (potentials versus $\mathrm{Fc} / \mathrm{Fc}^{+}$).

\begin{tabular}{|c|c|c|c|c|c|c|c|}
\hline $\mathrm{cmp}$. & $\begin{array}{c}E_{\text {onset, }_{\text {red }}} \\
(\mathrm{eV})\end{array}$ & $\begin{array}{c}E_{L U M O, C V}{ }^{b} \\
(\mathrm{eV})\end{array}$ & $E_{1 / 2^{I I^{*}}}$ & $E_{1 / 2^{I^{*}}}$ & $E_{1 / 2^{I}}$ & $E_{1 / 2^{I I}}$ & $E_{1 / 2}^{I I I}$ \\
\hline $\mathbf{1}$ & -1.74 & -3.06 & 1.12 & 0.87 & -1.84 & -2.04 & - \\
\hline $\mathbf{2}$ & -1.76 & -3.04 & 1.31 & 1.00 & -1.82 & -2.06 & -2.39 \\
\hline $\mathbf{3}$ & -1.84 & -2.96 & - & $1.09^{c}$ & -1.92 & -2.21 & -2.56 \\
\hline
\end{tabular}

${ }^{a}$ Estimated from the first reduction onset. ${ }^{b}$ Estimated from $\mathrm{CV}$ onset potential according to $E_{\mathrm{LUMO}}=-4.8-\mathrm{e}\left(E_{\text {onset,red. }}-E_{\mathrm{Fc}}{ }^{1 / 2}\right)$ where $E_{\mathrm{Fc}}^{1 / 2}$ was measured in situ $(\mathrm{eV}){ }^{\mathrm{c}} E_{\mathrm{pa}}$ 
Table S4. Orbitals eigenvalues at the B3LYP-CH $\mathrm{Cl}_{2}-6-311+\mathrm{g}(2 \mathrm{~d}, \mathrm{p}) / \mathrm{B} 3 \mathrm{LYP}-6-31 \mathrm{~g}(\mathrm{~d}, \mathrm{p})$ level. All energies are eV. MD: molecular dynamics.

\begin{tabular}{|c|c|c|c|c|c|c|c|}
\hline System & LUMO+2 & LUMO+1 & LUMO & HOMO & HOMO-1 & HOMO-2 & gap \\
\hline $\mathbf{1}$ (crystal) & -2.57 & -2.68 & -2.84 & -5.46 & -5.68 & -5.97 & 2.62 \\
\hline $\mathbf{2}$ (MD) & -2.56 & -2.72 & -2.81 & -5.47 & -5.67 & -5.94 & 2.66 \\
\hline $\mathbf{3}$ (crystal) & -2.57 & -2.74 & -2.79 & -5.44 & -5.67 & -5.9 & 2.65 \\
\hline
\end{tabular}




\section{Instrumentation and Materials}

Commercially available solvents and reagents were used without further purification unless otherwise noted.

2,6-dibromo-9,10-bis(2-(triisopropylsilyl)ethynyl)anthracene 8 were prepared according to reported

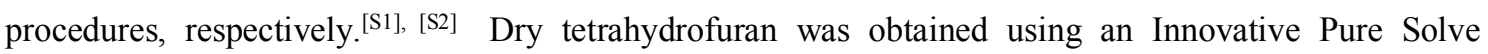
solvent purification system. The spectroscopic grade solvents were used as solvents for all spectroscopic studies.

Column chromatography was carried out using Silica gel $60(40-60 \mu \mathrm{m})$ from Scharlab. Analytical thin layer chromatography (TLC) was done using aluminum sheets $(20 \times 20 \mathrm{~cm})$ pre-coated with silica gel RP-18W 60 F254 from Merck.

${ }^{1} \mathrm{H}$ and ${ }^{13} \mathrm{C}$ NMR spectra were recorded on Bruker Avance 400 and 500 spectrometers at $298 \mathrm{~K}$ using partially deuterated solvents as internal standards. Coupling constants $(J)$ are denoted in $\mathrm{Hz}$ and chemical shifts $(\delta)$ in ppm. Multiplicities are denoted as follows: $\mathrm{s}=$ singlet, $\mathrm{d}=$ doublet, $\mathrm{t}=$ triplet, $\mathrm{m}=$ multiplet, br $=$ broad

High Resolution Matrix Assisted Laser Desorption Ionization (coupled to a Time-Of-Flight analyzer) Mass Spectrometry experiments were recorded in Biomagune in a Ultraflex III (Bruker Daltonics) MALDI-TOF (frequency-tripled (355 nm) Nd:YAG laser) by Dr. Javier Calvo.

X-ray diffraction experiments were performed by the X-ray diffraction unit of General Services SGIker of the University of the Basque Country by Dr. Leire San Felices. Intensity data were collected on an Agilent Technologies Super-Nova diffractometer, which was equipped with monochromated $\mathrm{Cu}$ ka radiation $(\lambda=1.54184 \mathrm{~A})$ and Atlas CCD detector. Measurement was carried out at 100(2) K with the help of an Oxford Cryostream 700 PLUS temperature device. Data frames were processed (united cell determination, analytical absorption correction with face indexing, intensity data integration and 
correction for Lorentz and polarization effects) using the Crysalis software package. The structure was solved using Olex2 and refined by full-matrix least-squares with SHELXL-97. Crystallographic data for 1 (CCDC-1978607) and 3 (CCDC-1978608) are deposited with the Cambridge Crystallographic Data Centre.

UV/visible absorption spectra were recorded on a Perkin-Elmer Lambda 950 spectrometer.

Fluorescence spectra were registered on a LS55 Perkin-Elmer Fluorescence spectrometer. Relative quantum yield was recorded with Rhodamine $6 \mathrm{G}$ as a reference $(\Phi=0.95$ in ethanol). All samples were measured in dichloromethane $\left(\lambda_{\mathrm{ex}}=450 \mathrm{~nm}\right)$.

Two-photon absorption measurements. Benzodipentaphenes 1-3 were dissolved in degassed toluene at 0.01-0.02 $\mathrm{mM}$ (the concentration was precisely determined by UV-vis spectroscopy and the extinction coefficient). The solutions were filled in a quartz cell with $1 \mathrm{~cm}$ optical path length. A femtosecond pulse $(1 \mathrm{kHz},<130 \mathrm{fs}$ duration, $1 \mathrm{~W})$ from a regenerative amplifier (Spectra Physics Inc., Spitfire) seeded by a Ti:sapphire laser (Spectra Physics Inc., Tsunami) was used for TPA experiments with focusing using a 10 cm convex lens. The photoluminescence spectrum was recorded through IR cutting filters $(>800 \mathrm{~nm})$ using an Ocean Optics Inc. model HR4000GG-UV-NIR spectrometer. ${ }^{[33]}$

Electrochemical measurements were carried out on a Princeton Applied Research Parstat 2273 in a 3-electrode single compartment cell with glassy carbon disc working electrode, a platinum wire counter electrode and a silver wire pseudoreference electrode. All the potential values are reported versus the redox potential of the ferrocene/ferrocenium couple.

All calculations were carried out using the Gaussian 09 program. ${ }^{[54]}$ Initial geometries were obtained from X-ray structures for $\mathbf{1}$ and $\mathbf{3}$. For compound $\mathbf{2}$, refining structures obtained from molecular dynamics calculations with the GFN2-xTB method (Geometry, Frequency, Non-covalent, eXtended 
Tight-Binding. ${ }^{[55]}$ The structures were fully optimized without any symmetry restriction. Geometry optimizations in the ground state $\left(\mathrm{S}_{0}\right)$ were performed by the density functional theory (DFT) method with restricted B3LYP (Becke's three-parameter hybrid exchange functionals and the Lee-Yang-Parr correlation functional) level employing a basis set of 6-31g(d,p). 


\section{Synthesis}

\section{9,10-bis(2-(triisopropylsilyl)ethynyl)anthracene-2,6-diol (10)}

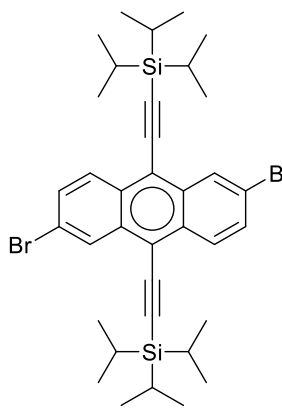

8

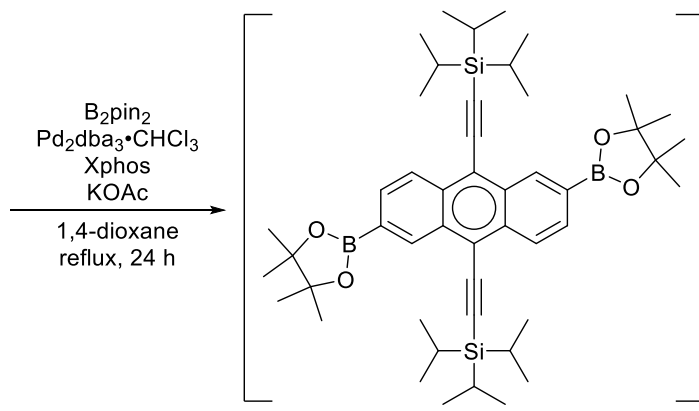

9

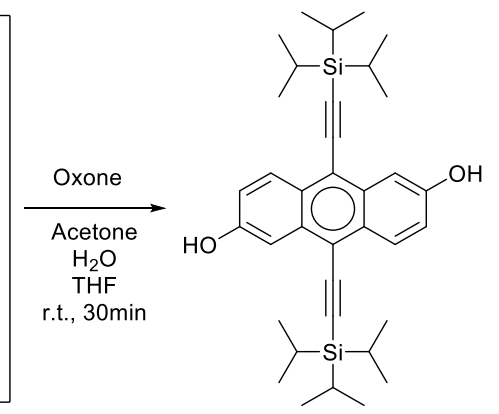

10

To a Schlenk tube was charged 2,6-dibromo-9,10-bis(2-(triisopropylsilyl)ethynyl)anthracene $\mathbf{8}^{[\mathrm{S} 2]}$ (3.472 g, $5.0 \mathrm{mmol}), \mathrm{Pd}_{2}(\mathrm{dba})_{3} \cdot \mathrm{CHCl}_{3}(517.5 \mathrm{mg}, 10 \mathrm{~mol} \%), \mathrm{X}-\mathrm{Phos}(0.476 \mathrm{mg}, 20 \mathrm{~mol} \%), \mathrm{KOAc}(1.47 \mathrm{~g}, 3 \mathrm{eq})$, and bis(pinacolato)diboron $(3.80 \mathrm{~g}, 3.0 \mathrm{eq})$. The flask was evacuated and then refilled with $\mathrm{N}_{2}$ for three times. Then, dry 1,4-dioxane $(150 \mathrm{~mL})$ was added. The mixture was stirred at reflux in an oil bath for 48 h. After cooling, the reaction mixture was diluted with DCM, and filtered over a pad of Celite (EtOAc as an eluent). The solvent was evaporated, and the residue was used in the next step without further purification as there were signs of fast decomposition. ${ }^{1} \mathrm{H}-\mathrm{NMR}\left(400 \mathrm{M} \mathrm{Hz}, \mathrm{CDCl}_{3}, \mathrm{ppm}\right) \delta 9.24(\mathrm{~s}, 2 \mathrm{H})$, $8.58(\mathrm{~d}, J=8.6 \mathrm{~Hz}, 2 \mathrm{H}), 7.90(\mathrm{~d}, J=8.6 \mathrm{~Hz}, 2 \mathrm{H}), 1.38(\mathrm{~s}, 24 \mathrm{H}), 1.28-1.26(\mathrm{~m}, 42 \mathrm{H})$.

To a solution of the residue obtained above (compound 9 ) in a mixture of dry THF (280 mL), acetone (40 $\mathrm{mL})$ and water $(20 \mathrm{~mL})$ were added oxone $(15.46 \mathrm{~g}, 25.0 \mathrm{mmol})$ under $\mathrm{N}_{2}$. The reaction was stirred at room temperature overnight, and then was quenched with aqueous $\mathrm{Na}_{2} \mathrm{~S}_{2} \mathrm{O}_{3}$, and extracted with ethyl acetate. The combined organic layers were washed with water and brine, dried over anhydrous $\mathrm{Na}_{2} \mathrm{SO}_{4}$. The target product $10(1.276 \mathrm{~g}, 45 \%)$ was purified by silica-gel column chromatography (with hexane/EtOAc as eluent) as yellow solids. ${ }^{1} \mathrm{H}-\mathrm{NMR}\left(400 \mathrm{M} \mathrm{Hz}, \mathrm{CDCl}_{3}, \mathrm{ppm}\right) \delta 8.51(\mathrm{~d}, J=9.2 \mathrm{~Hz}, 2 \mathrm{H})$, $7.82(\mathrm{~d}, J=2.4 \mathrm{~Hz}, 2 \mathrm{H}), 7.26-7.23(\mathrm{~m}, 4 \mathrm{H}), 5.11(\mathrm{br}, 2 \mathrm{H}), 1.26-1.23(\mathrm{~m}, 42 \mathrm{H}) .{ }^{13} \mathrm{C}-\mathrm{NMR}(101 \mathrm{M} \mathrm{Hz}$, $\left.\mathrm{CDCl}_{3}, \mathrm{ppm}\right) \delta=153.7,132.5,129.4,120.5,116.7,107.8,104.3,103.6,19.1,11.7$. HR-APCI-TOF-MS: $m / z$ calcd for $\mathrm{C}_{36} \mathrm{H}_{50} \mathrm{O}_{2} \mathrm{Si}_{2}[\mathrm{M}+\mathrm{H}]^{+}, 571.3428$, found 571.3424 . 


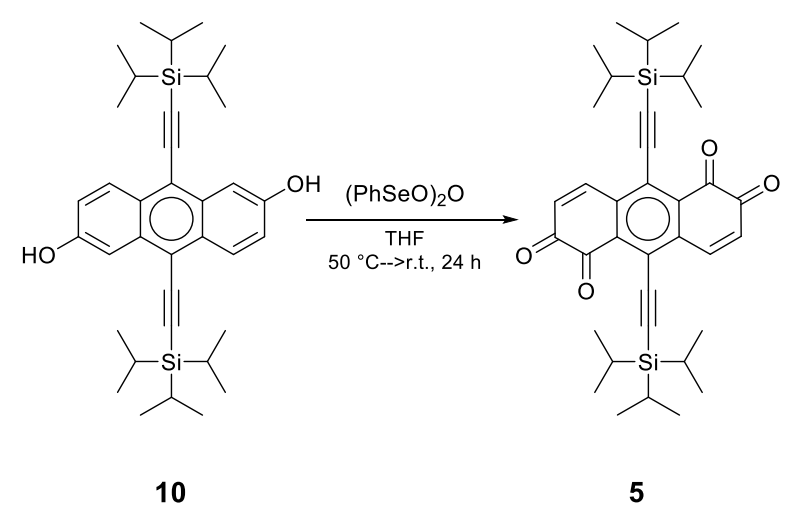

A solution of $10(2.443 \mathrm{~g}, 4.28 \mathrm{mmol})$ in dry THF $(100 \mathrm{~mL})$ was added to a solution of phenylseleninic anhydride $(4.746 \mathrm{~g}, 13.5 \mathrm{mmol})$ in dry THF $(200 \mathrm{~mL})$ at $50{ }^{\circ} \mathrm{C}$ in an oil bath under nitrogen. The reaction was stirred at room temperature for $24 \mathrm{~h}$. Then, the mixture was diluted with DCM, and washed with aquous $\mathrm{NaHCO}_{3}$. The combined organic layer was wahsed with water and brine, and dried over anhydrous $\mathrm{Na}_{2} \mathrm{SO}_{4}$. Purification by silica-gel column chromatography (with hexane/EtOAc as eluent) afforded the target compound $5(1.77 \mathrm{~g}, 69 \%)$ as red solids. ${ }^{1} \mathrm{H}-\mathrm{NMR}\left(400 \mathrm{M} \mathrm{Hz}, \mathrm{CDCl}_{3}, \mathrm{ppm}\right) \delta 8.46(\mathrm{~d}$, $J=10.5 \mathrm{~Hz}, 2 \mathrm{H}), 6.67(\mathrm{~d}, J=10.5 \mathrm{~Hz}, 2 \mathrm{H}), 1.20-1.17(\mathrm{~m}, 42 \mathrm{H}) .{ }^{13} \mathrm{C}-\mathrm{NMR}\left(101 \mathrm{M} \mathrm{Hz}, \mathrm{CDCl}_{3}, \mathrm{ppm}\right) \delta=$ 179.3, 177.0, 141.6, 139.1, 135.7, 129.8, 124.1, 112.7, 100.0, 18.8, 11.4. HR-MALDI-TOF-MS: $m / z$ calcd for $\mathrm{C}_{36} \mathrm{H}_{46} \mathrm{O}_{4} \mathrm{Si}_{2}[\mathrm{M}+\mathrm{H}]^{+}, 599,3007$, found 599,3054. 


\section{6,11-bis(2-(triisopropylsilyl)ethynyl)anthra[2,1-c][1,2,5]thiadiazole (7)}

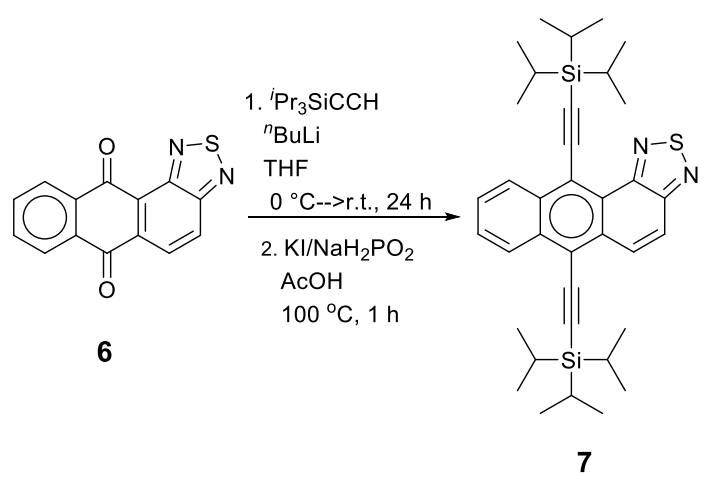

Tri-iso-propylsilyl acetylene $(6.7 \mathrm{~mL}, 30.0 \mathrm{mmol})$ was dissolved in dry THF $(100 \mathrm{~mL})$, and the reaction system was cooled to $0{ }^{\circ} \mathrm{C}$. Then, $n$-BuLi $(13.0 \mathrm{~mL}, 2.5 \mathrm{M}$ in hexane, $32.5 \mathrm{mmol})$ was added slowly. After stirring for $1.5 \mathrm{~h}$ at room temperature, anthra[2,1-c][1,2,5]thiadiazole-6,11-dione $\mathbf{6}^{[\mathrm{S} 1]}(2.66 \mathrm{~g}, 10.0$ mmol) in THF (200 mL) was added slowly, and the resulting mixture was stirred at room temperature for $24 \mathrm{~h}$. The reaction was quenched with aqueous ammonium chloride $(50 \mathrm{~mL})$, followed by extraction with ethyl acetate. The combined organic layer was washed with water and brine, and dried over $\mathrm{Na}_{2} \mathrm{SO}_{4}$. The solvents were removed and the resulting intermediate product was dissolved in acetic acid $(200 \mathrm{~mL})$. Potassium iodide $(8.30 \mathrm{~g}, 50.0 \mathrm{mmol})$ and sodium hypophosphite $(4.40 \mathrm{~g}, 50.0 \mathrm{mmol})$ was added and the mixture was heated to $100{ }^{\circ} \mathrm{C}$ in an oil bath for $1 \mathrm{~h}$. After cooling to ambient temperature the reaction mixture was poured into water and extraction with ethyl acetate. The combined organic layer was washed with water and brine, and dried over $\mathrm{Na}_{2} \mathrm{SO}_{4}$. Purification by silica-gel column chromatography ( with hexane/DCM as eluent) gives the target product $7(4.81 \mathrm{~g}, 80 \%)$ as pale yellow solids. ${ }^{1} \mathrm{H}-\mathrm{NMR}$ (400 M $\left.\mathrm{Hz}, \mathrm{CDCl}_{3}, \mathrm{ppm}\right) \delta 8.96-8.91(\mathrm{~m}, 1 \mathrm{H}), 8.72-8.67(\mathrm{~m}, 2 \mathrm{H}), 7.86(\mathrm{~d}, \mathrm{~J}=9.6 \mathrm{~Hz}, 1 \mathrm{H}), 7.79-7.73(\mathrm{~m}, 2 \mathrm{H})$, $1.33-1.25(\mathrm{~m}, 42 \mathrm{H}) .{ }^{13} \mathrm{C}-\mathrm{NMR}\left(101 \mathrm{M} \mathrm{Hz}, \mathrm{CDCl}_{3}, \mathrm{ppm}\right) \delta 155.5,153.7,133.8,133.1,132.6,131.7,128.3$, $128.2,127.9,127.5,125.4,121.1,120.3,119.2,108.1,105.8,104.1,102.8,19.0,11.9,11.6$. HR-APCI-TOF-MS: $m / z$ calcd for $\mathrm{C}_{36} \mathrm{H}_{48} \mathrm{~N}_{2} \mathrm{SSi}_{2}[\mathrm{M}+\mathrm{H}]^{+}, 597.3155$, found 597.3158. 


\section{Benzobispentaphenes 1, 2 and 3}
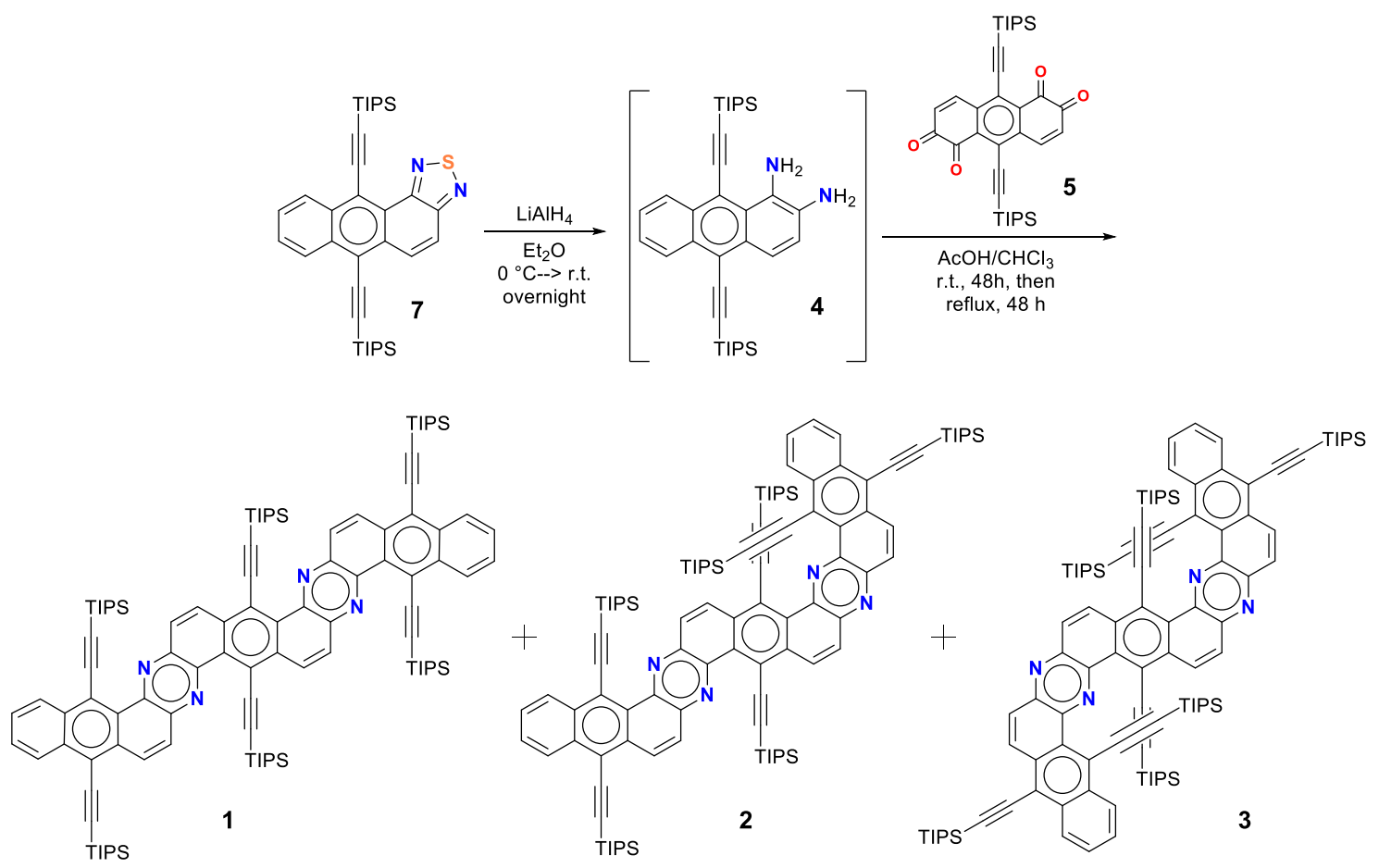

To a Schlenk was charged $7(0.537 \mathrm{~g}, 0.9 \mathrm{mmol})$ and diethyl ether $(150 \mathrm{~mL})$ at $0{ }^{\circ} \mathrm{C}$. An excess of lithium aluminum hybride $(11.25 \mathrm{~mL}, 4 \mathrm{M}$ in diethyl ether, $45 \mathrm{mmol})$ was added dropwise under nitrogen, and the reaction mixture was stirred overnight at room temperature. Then, the reaction was quenched with saturated $\mathrm{NH}_{4} \mathrm{Cl}$ (aq.), and extracted with DCM. The combined organic layers were washed with water and brine, and dried over anhydrous $\mathrm{Na}_{2} \mathrm{SO}_{4}$. After removal of the solvents, the residue was used directly in the next step as there were signs of fast decomposition.

To a Schlenk tube was charged the above residue (diamine 4), tetraone 5 (179.5 $\mathrm{mg}, 0.3 \mathrm{mmol}$ ) and a mixture of acetic acid/chloroform $(30 / 60 \mathrm{~mL})$ were added under nitrogen. The reaction stirred at room temperature for $48 \mathrm{~h}$, and then heated to reflux in an oil bath for $48 \mathrm{~h}$. After cooling to room temperature, the reaction was quenched with saturated $\mathrm{NH}_{4} \mathrm{Cl}$ (aq.), and the mixture was extracted with DCM. The combined organic layers were washed with brine, and dried over $\mathrm{Na}_{2} \mathrm{SO}_{4}$. After removal of the solvents, the crude product was purified with column chromatography on silica gel with hexane/DCM as eluent to offered $\mathbf{1}$ (36.0 $\mathrm{mg}, 7.2 \%), \mathbf{2}(55.9 \mathrm{mg}, 11.2 \%)$, and $\mathbf{3}(8.1 \mathrm{mg}, 1.6 \%)$ as orange solids. 
1: ${ }^{1} \mathrm{H}$ NMR (500 MHz, $\left.\mathrm{CDCl}_{3}, \mathrm{ppm}\right) \delta 9.50(\mathrm{~d}, J=9.5 \mathrm{~Hz}, 2 \mathrm{H}), 9.17-9.15(\mathrm{~m}, 2 \mathrm{H}), 8.91(\mathrm{~d}, J=9.5 \mathrm{~Hz}$, $2 \mathrm{H}), 8.76-8.74(\mathrm{~m}, 2 \mathrm{H}), 8.46(\mathrm{~d}, J=9.5 \mathrm{~Hz}, 2 \mathrm{H}), 8.26(\mathrm{~d}, J=9.5 \mathrm{~Hz}, 2 \mathrm{H}), 7.80-7.78(\mathrm{~m}, 4 \mathrm{H}), 1.36-1.31$ (m, 126H). ${ }^{13} \mathrm{C}$ NMR (126 MHz, $\left.\mathrm{CDCl}_{3}, \mathrm{ppm}\right) \delta 143.4,141.8,141.7,141.1,136.1,134.7,133.7,133.4$, $131.3,131.1,130.7,129.3,129.2,128.9,128.6,128.2,127.8,127.5,120.2,120.0,119.8,108.2,108.1$, 106.7, 106.4, 105.7, 103.5, 19.2, 19.1, 12.19, 12.17, 11.9. HR-MALDI-TOF-MS: $\mathrm{m} / \mathrm{z}$ calcd for $\mathrm{C}_{108} \mathrm{H}_{142} \mathrm{~N}_{4} \mathrm{Si}_{6}[\mathrm{M}+\mathrm{H}]^{+}, 1663.9927$, found 1663.9995.

2: ${ }^{1} \mathrm{H}$ NMR (500 MHz, $\left.\mathrm{CDCl}_{3}, \mathrm{ppm}\right) \delta 9.32(\mathrm{~d}, J=9.5 \mathrm{~Hz}, 1 \mathrm{H}), 9.27(\mathrm{~d}, J=9.5 \mathrm{~Hz}, 1 \mathrm{H}), 9.21-9.14(\mathrm{~m}$, 1H), $9.02-8.93(\mathrm{~m}, 1 \mathrm{H}), 8.91(\mathrm{~d}, J=9.5 \mathrm{~Hz}, 1 \mathrm{H}), 8.81-8.71(\mathrm{~m}, 3 \mathrm{H}), 8.43(\mathrm{~d}, J=9.5 \mathrm{~Hz}, 1 \mathrm{H}), 8.28(\mathrm{~d}$, $J=9.5 \mathrm{~Hz}, 1 \mathrm{H}), 8.17(\mathrm{~d}, J=9.5 \mathrm{~Hz}, 1 \mathrm{H}), 7.97(\mathrm{~d}, J=9.5 \mathrm{~Hz}, 1 \mathrm{H}), 7.85-7.70(\mathrm{~m}, 4 \mathrm{H}), 1.35-1.28(\mathrm{~m}$, $84 \mathrm{H}), 0.81-0.77(\mathrm{~m}, 9 \mathrm{H}), 0.76-0.70(\mathrm{~m}, 10 \mathrm{H}), 0.68-0.63(\mathrm{~m}, 12 \mathrm{H}), 0.62-0.61(\mathrm{~m}, 11 \mathrm{H}) .{ }^{13} \mathrm{C}$ NMR $(126$ $\left.\mathrm{MHz}, \mathrm{CDCl}_{3}, \mathrm{ppm}\right) \delta 143.2,143.1,142.1,141.7,141.5,140.9,139.1,138.0,135.6,135.4,134.5,134.1$, $133.5,133.30,133.26,132.1,131.6,131.4,131.23,131.16,130.4,129.8,129.2,128.9,128.6,128.5$, $128.3,128.1,128.0,127.9,127.7,127.4,127.3,121.1,120.9,120.0,119.9,119.00,118.9,108.0,107.0$ $106.3,106.0,105.8,105.7,105.2,104.8,103.9,103.2,103.0,19.20,19.19,19.1,19.0,18.6,18.54,18.52$, 18.4, 12.0, 11.7, 11.5. HR-MALDI-TOF-MS: $m / z$ calcd for $\mathrm{C}_{108} \mathrm{H}_{142} \mathrm{~N}_{4} \mathrm{Si}_{6}[\mathrm{M}+\mathrm{H}]^{+}, 1663.9927$, found 1664.0057.

3: ${ }^{1} \mathrm{H}$ NMR $\left(500 \mathrm{MHz}, \mathrm{CDCl}_{3}, \mathrm{ppm}\right) \delta 9.14(\mathrm{~d}, J=9.4 \mathrm{~Hz}, 2 \mathrm{H}), 8.96-8.90(\mathrm{~m}, 2 \mathrm{H}), 8.76-8.71(\mathrm{~m}, 4 \mathrm{H})$, $8.10(\mathrm{~d}, J=9.4 \mathrm{~Hz}, 2 \mathrm{H}), 7.95(\mathrm{~d}, J=9.3 \mathrm{~Hz}, 2 \mathrm{H}), 7.82-7.71(\mathrm{~m}, 4 \mathrm{H}), 1.34-1.30(\mathrm{~m}, 42 \mathrm{H}), 0.78-0.75(\mathrm{~m}$, 42H), $0.67-0.62$ (m, 42H). ${ }^{13} \mathrm{C}$ NMR (126 MHz, $\left.\mathrm{CDCl}_{3}, \mathrm{ppm}\right) \delta 142.7,141.8,138.6,137.5,135.6,134.0$, $133.4,133.2,132.3,132.0,130.5,130.0,128.5,128.1,127.8,127.7,127.6,127.3,121.2,119.7,118.8$, $105.81,105.79,105.4,105.1,103.2,103.0,19.1,18.6,18.53,18.51,18.49,11.7,11.6,11.5$. HR-MALDI-TOF-MS: $m / z$ calcd for $\mathrm{C}_{108} \mathrm{H}_{142} \mathrm{~N}_{4} \mathrm{Si}_{6}[\mathrm{M}+\mathrm{H}]^{+}, 1663.9927$, found 1663.9925. 


\section{NMR Spectra}

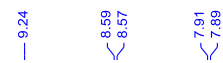
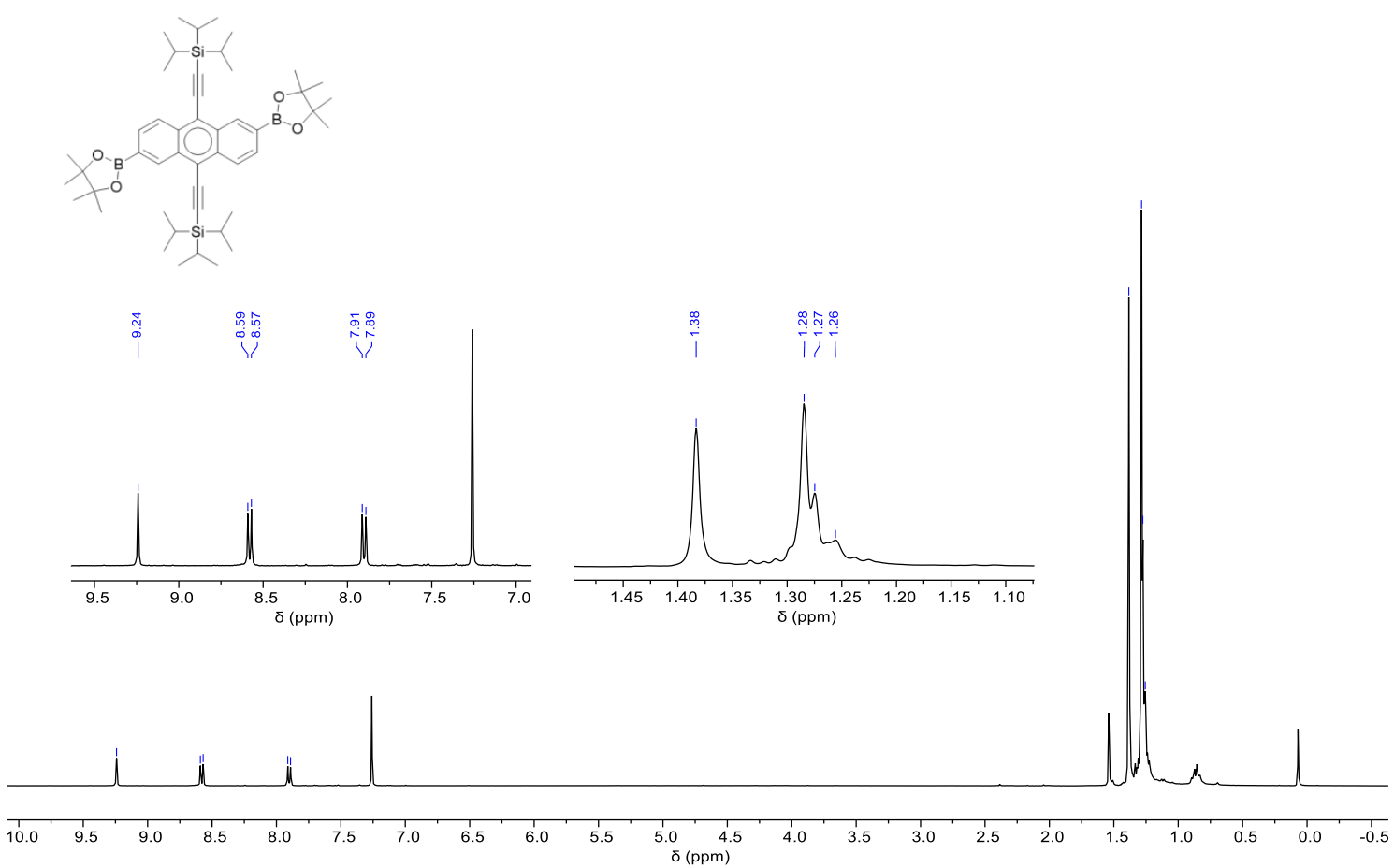

Figure S3-1. ${ }^{1} \mathrm{H}$ NMR spectrum of 9 in $\mathrm{CDCl}_{3}$ at room temperature $(400 \mathrm{MHz})$. 


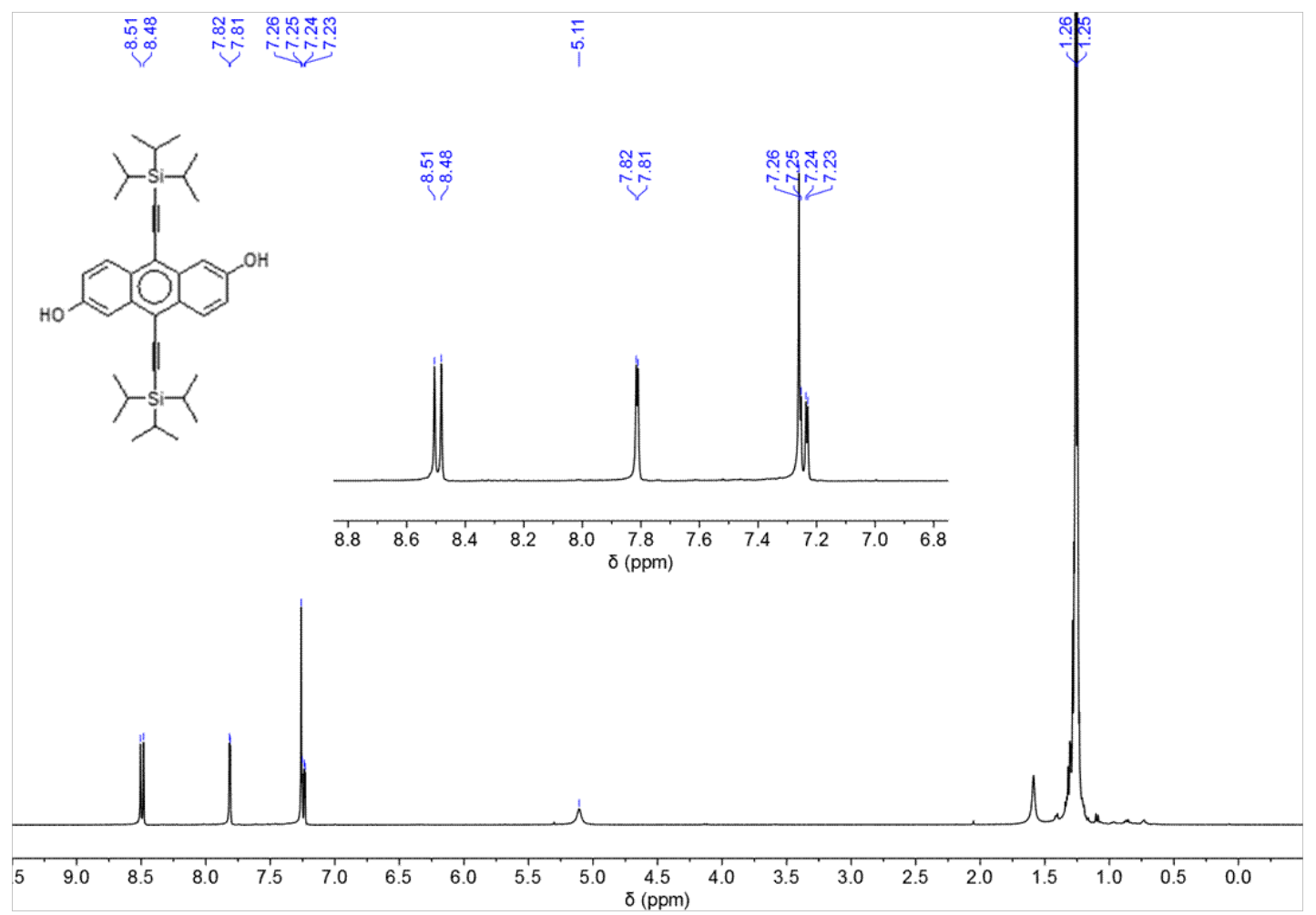

Figure S3-2. ${ }^{1} \mathrm{H}$ NMR spectrum of 10 in $\mathrm{CDCl}_{3}$ at room temperature $(400 \mathrm{MHz})$. 


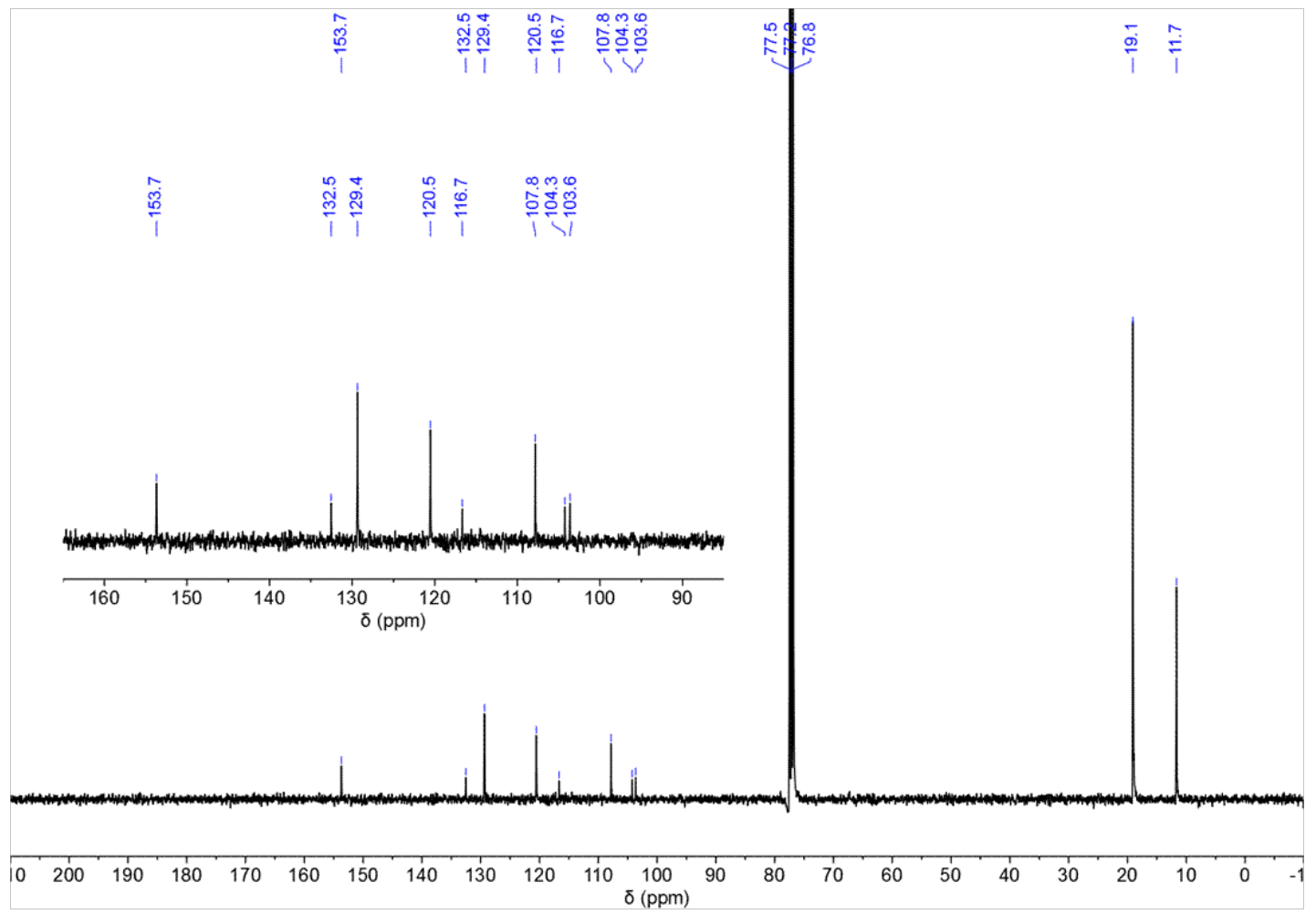

Figure S3-3. ${ }^{13} \mathrm{C}$ NMR spectrum of $\mathbf{1 0}$ in $\mathrm{CDCl}_{3}$ at room temperature $(400 \mathrm{MHz})$. 


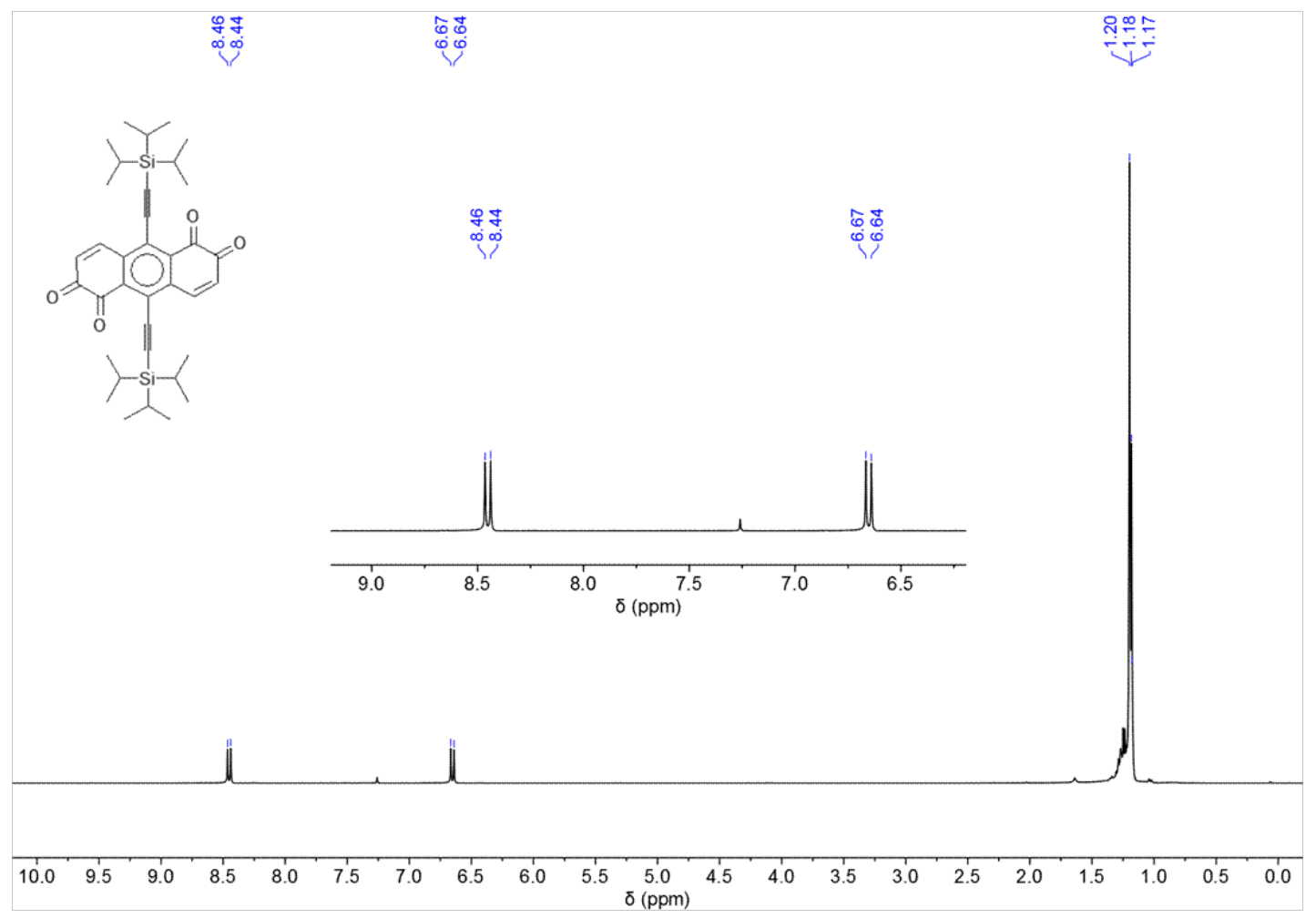

Figure S3-4. ${ }^{1} \mathrm{H}$ NMR spectrum of 5 in $\mathrm{CDCl}_{3}$ at room temperature $(400 \mathrm{MHz})$. 


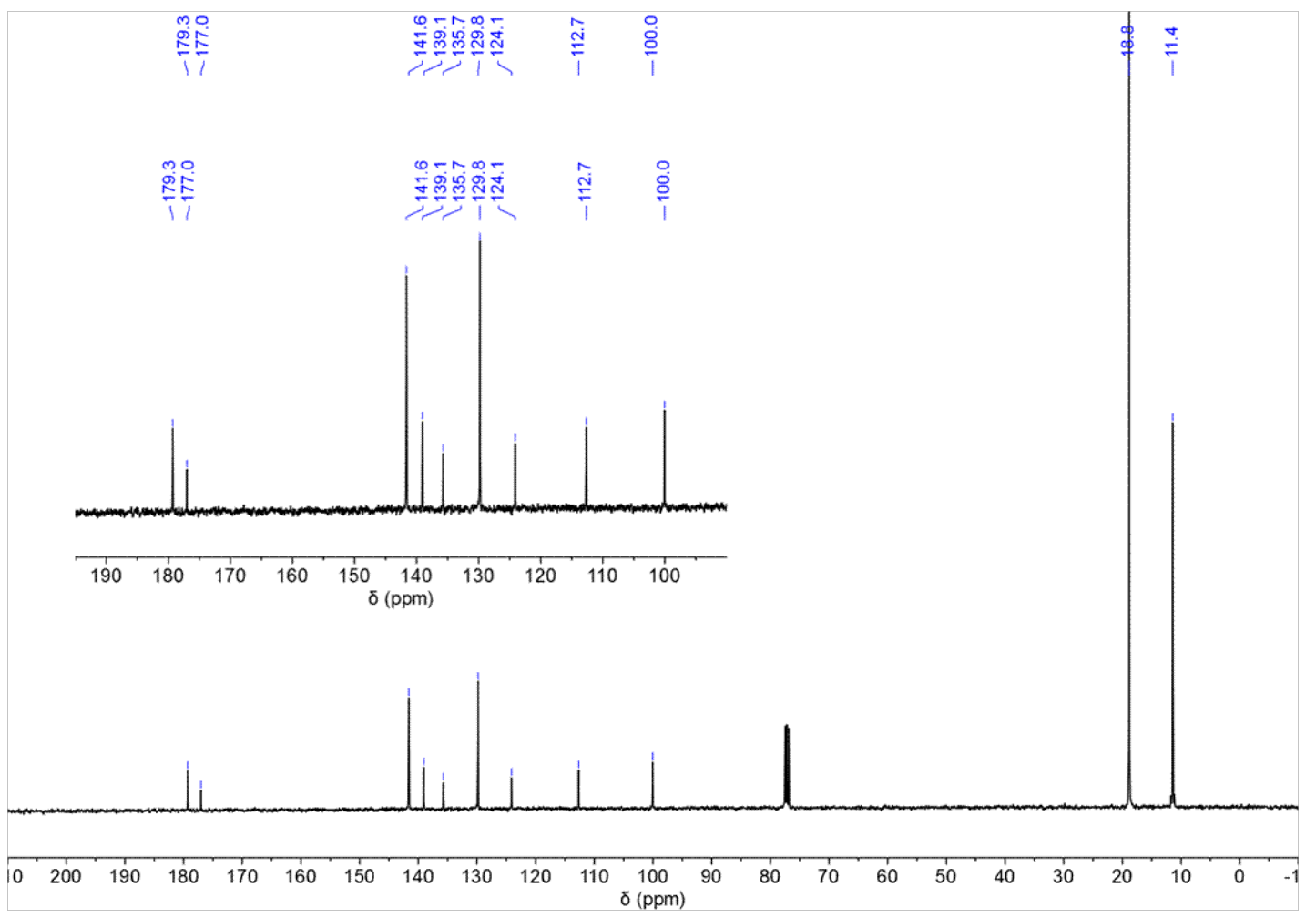

Figure S3-5. ${ }^{13} \mathrm{C}$ NMR spectrum of 5 in $\mathrm{CDCl}_{3}$ at room temperature $(400 \mathrm{MHz})$. 


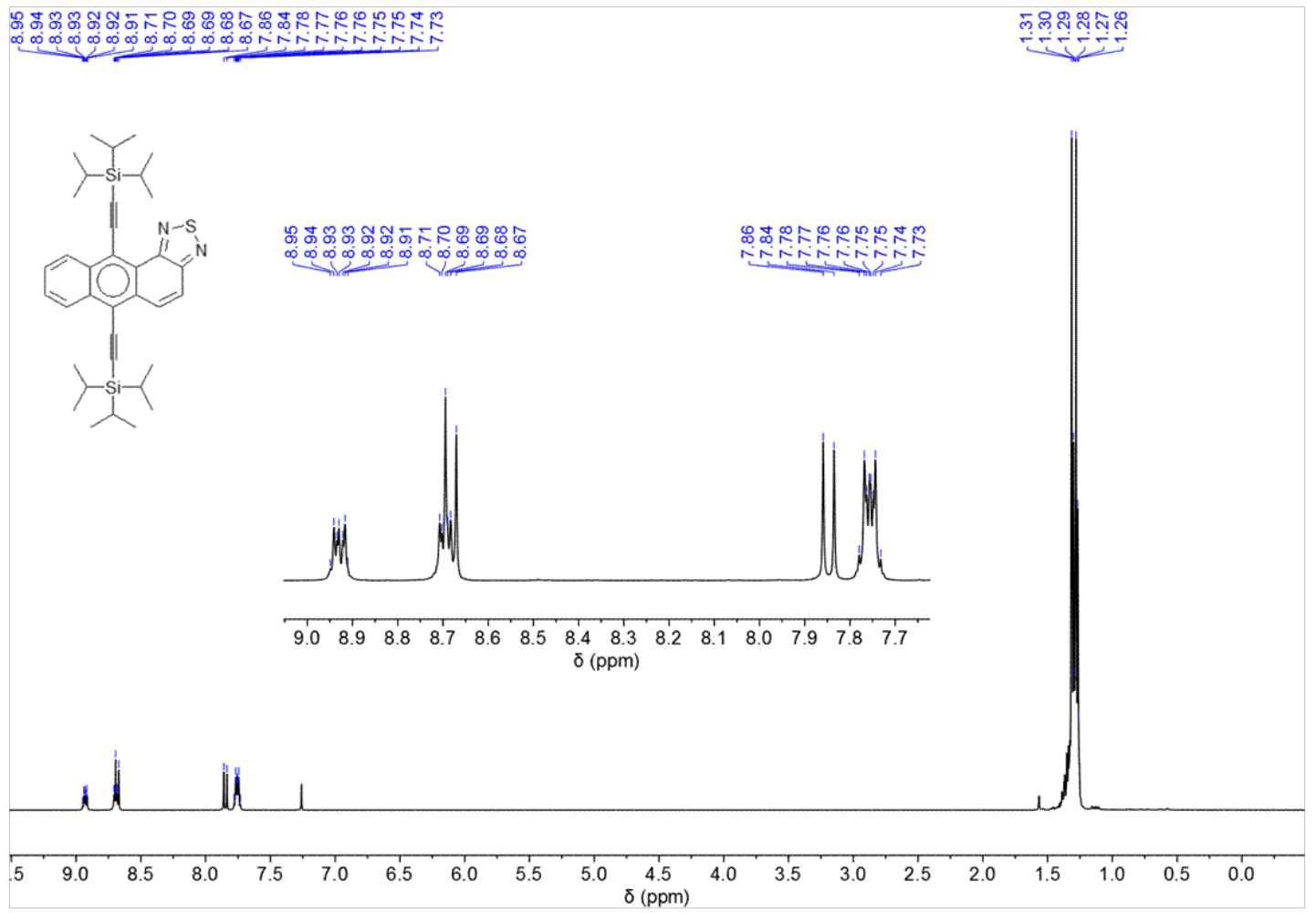

Figure S3-6. ${ }^{1} \mathrm{H}$ NMR spectrum of 7 in $\mathrm{CDCl}_{3}$ at room temperature $(400 \mathrm{MHz})$. 


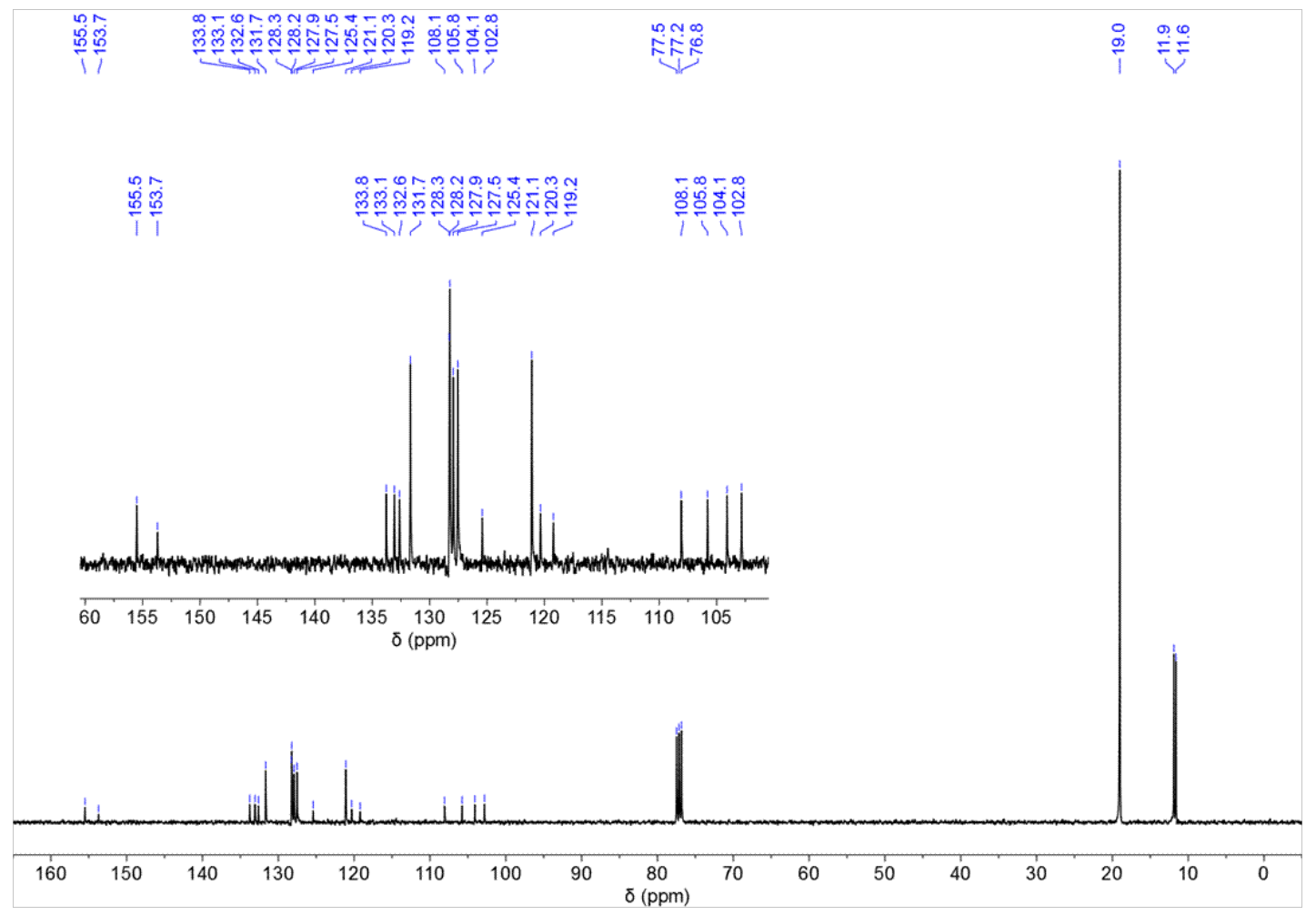

Figure S3-7. ${ }^{1} \mathrm{H}$ NMR spectrum of 7 in $\mathrm{CDCl}_{3}$ at room temperature $(400 \mathrm{MHz})$. 


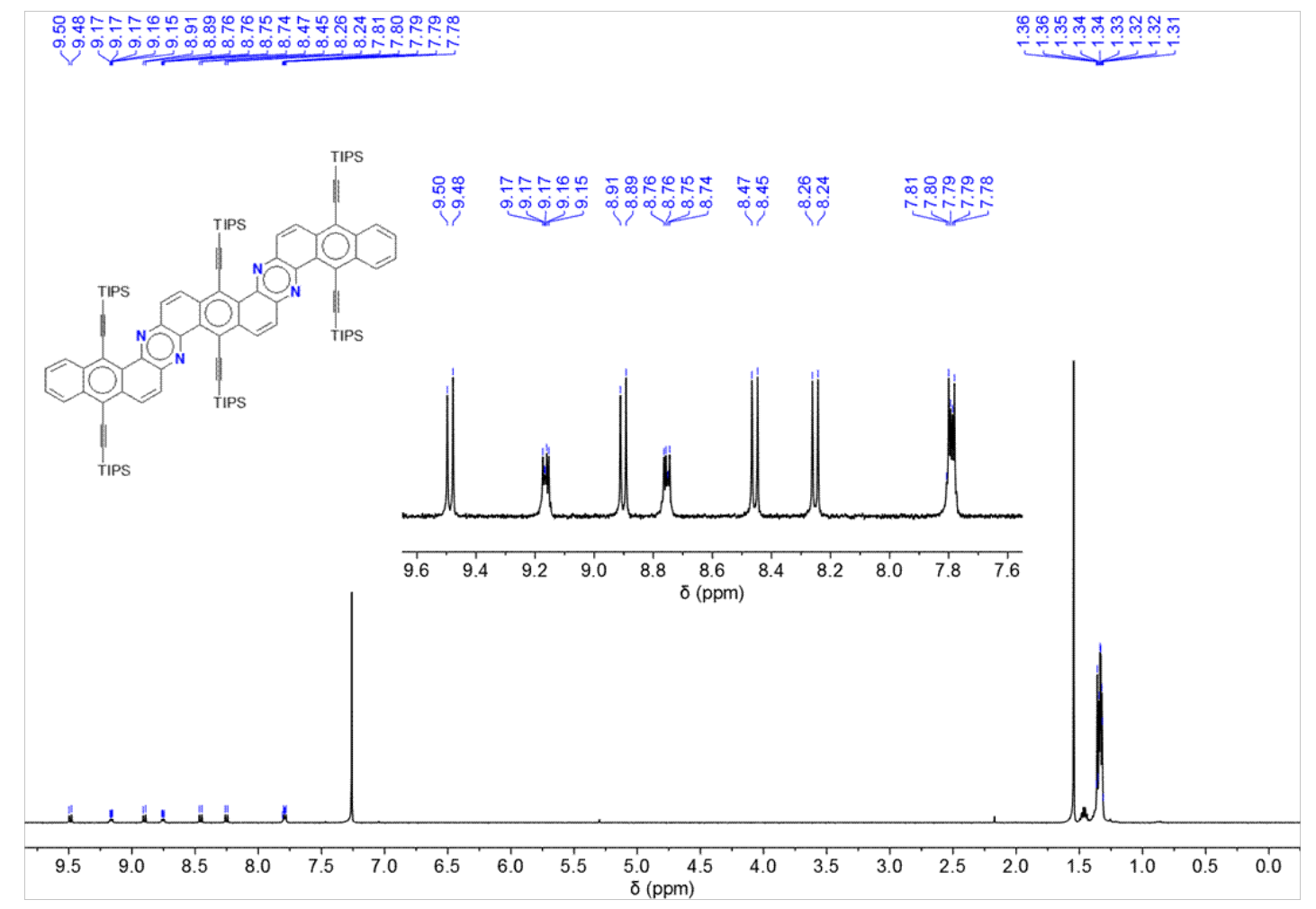

Figure S3-8. ${ }^{1} \mathrm{H}$ NMR spectrum of 1 in $\mathrm{CDCl}_{3}$ at room temperature $(500 \mathrm{MHz})$. 


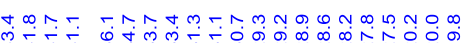

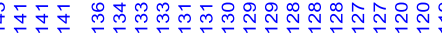

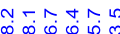

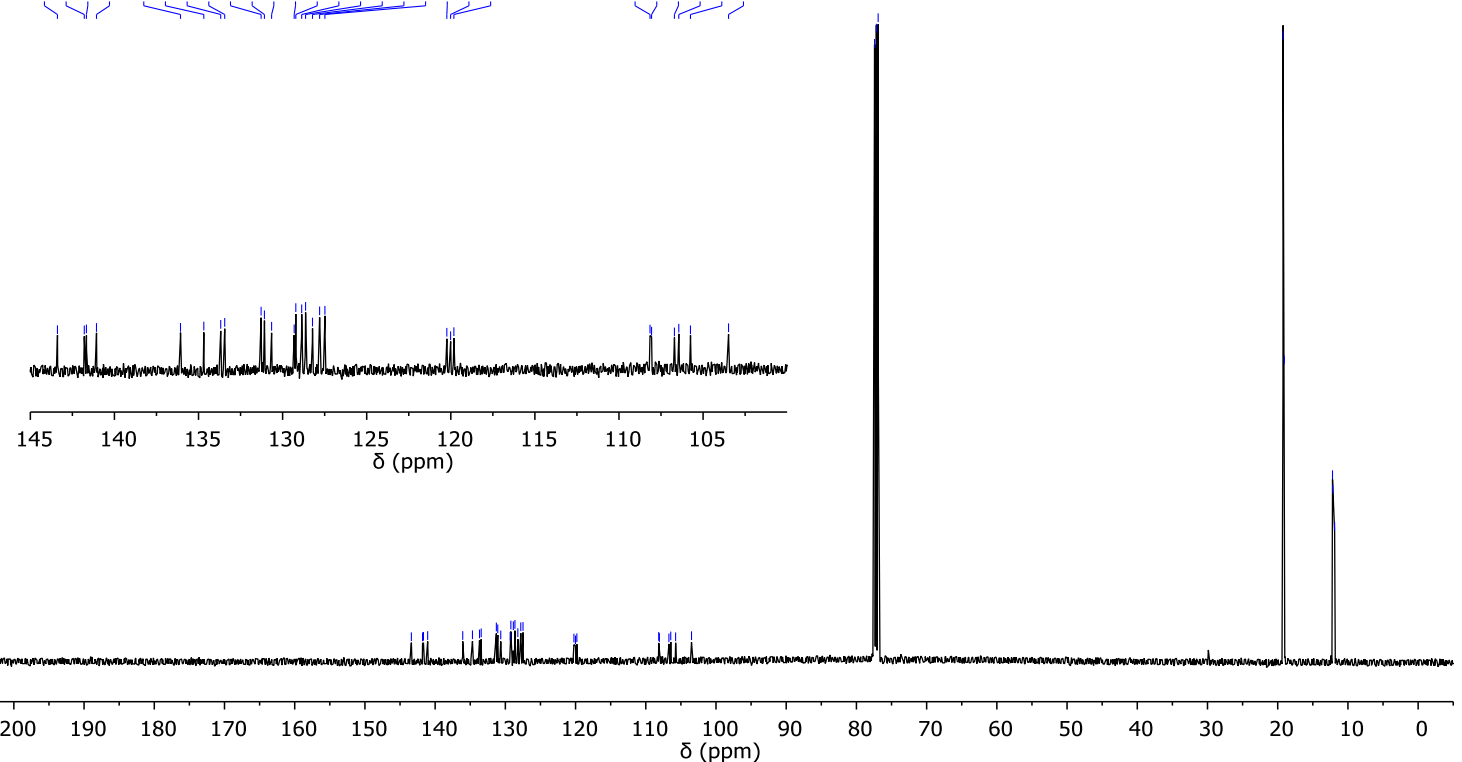

Figure S3-9. ${ }^{13} \mathrm{C}$ NMR spectrum of 1 in $\mathrm{CDCl}_{3}$ at $50{ }^{\circ} \mathrm{C}(500 \mathrm{MHz})$. 


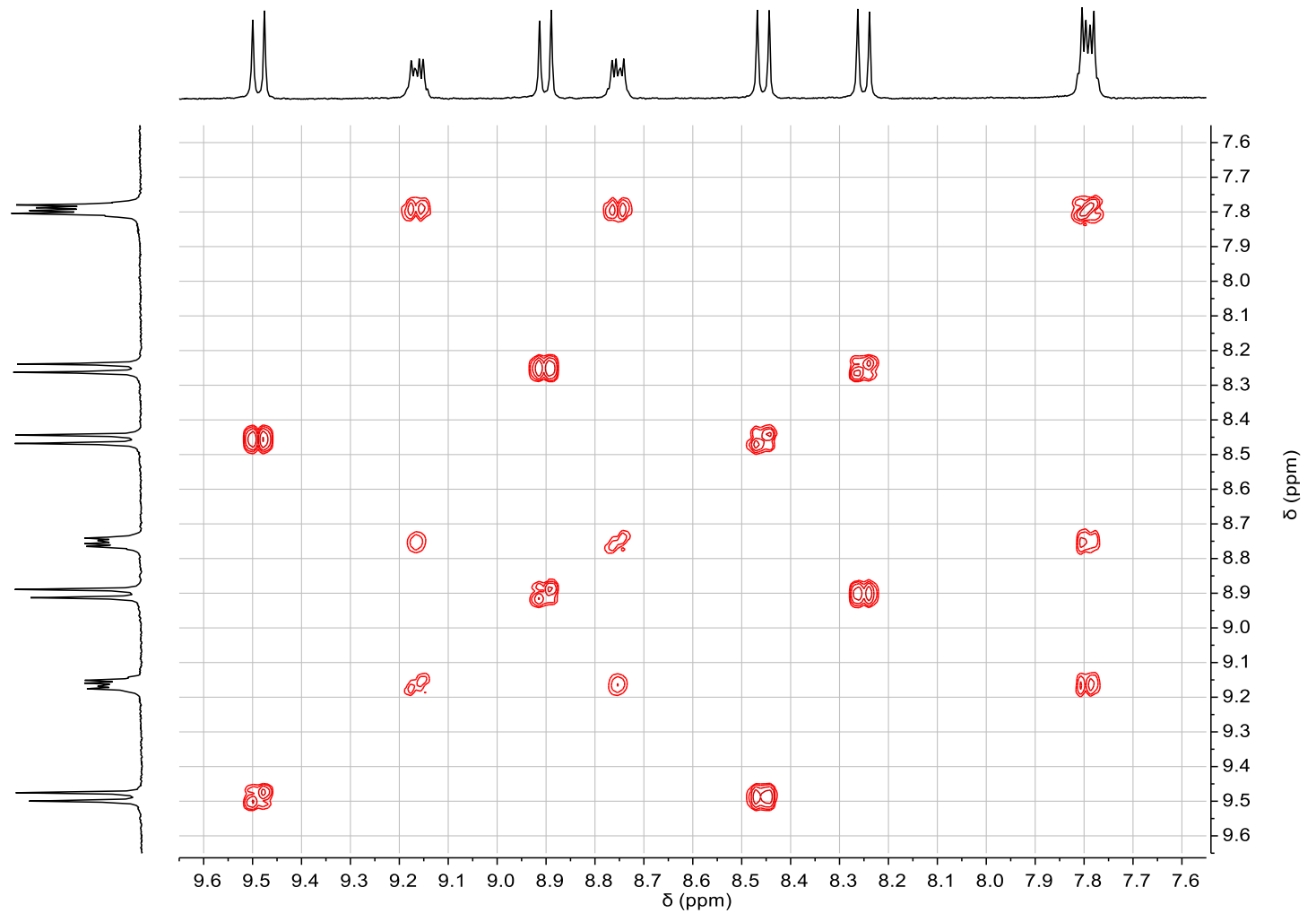

Figure S3-10. ${ }^{1} \mathrm{H}-{ }^{1} \mathrm{H}$ COSY chart of 1 in $\mathrm{CDCl}_{3}$ at room temperature $(500 \mathrm{MHz})$. 


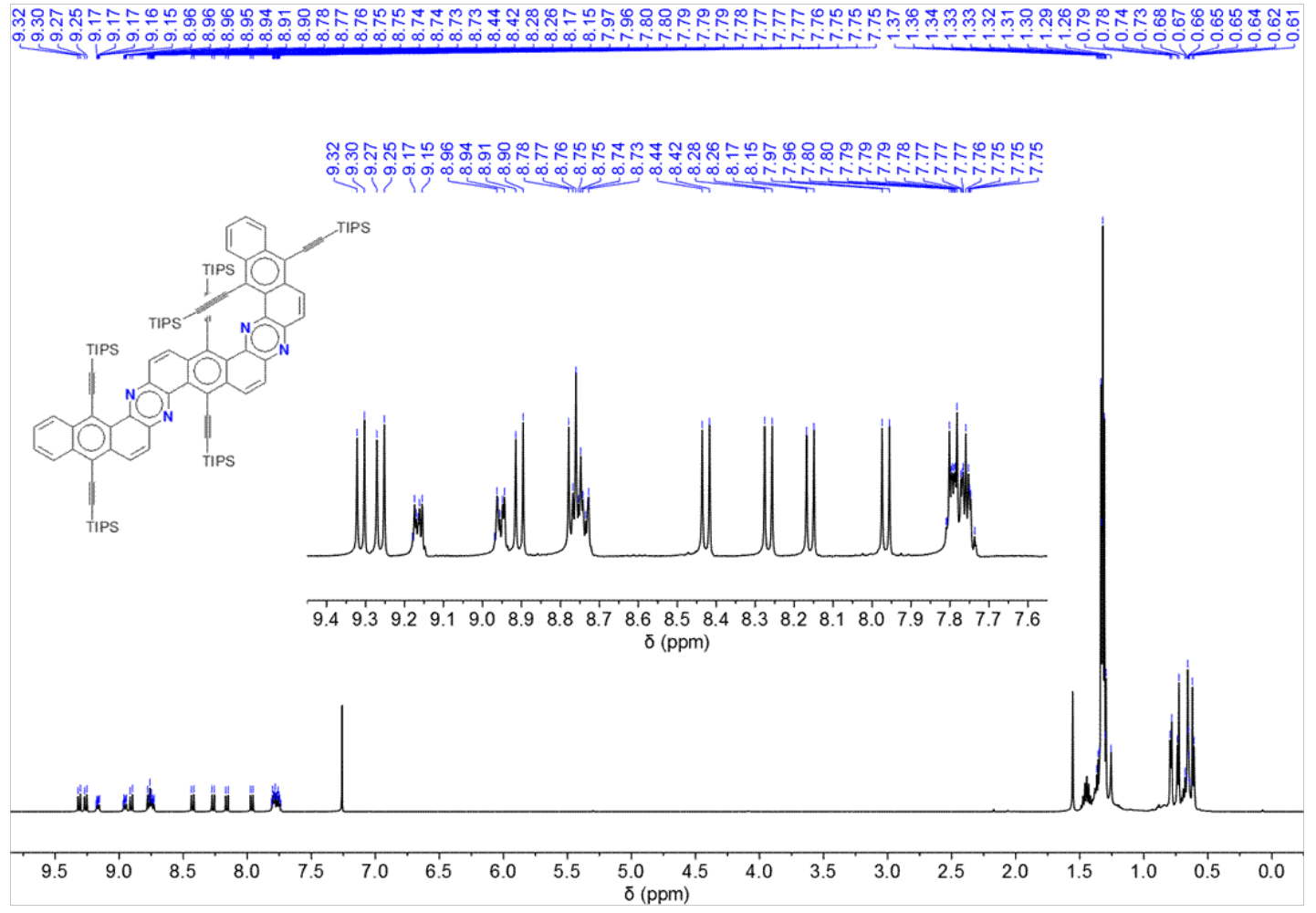

Figure S3-11. ${ }^{1} \mathrm{H}$ NMR spectrum of 2 in $\mathrm{CDCl}_{3}$ at room temperature $(500 \mathrm{MHz})$. 
1

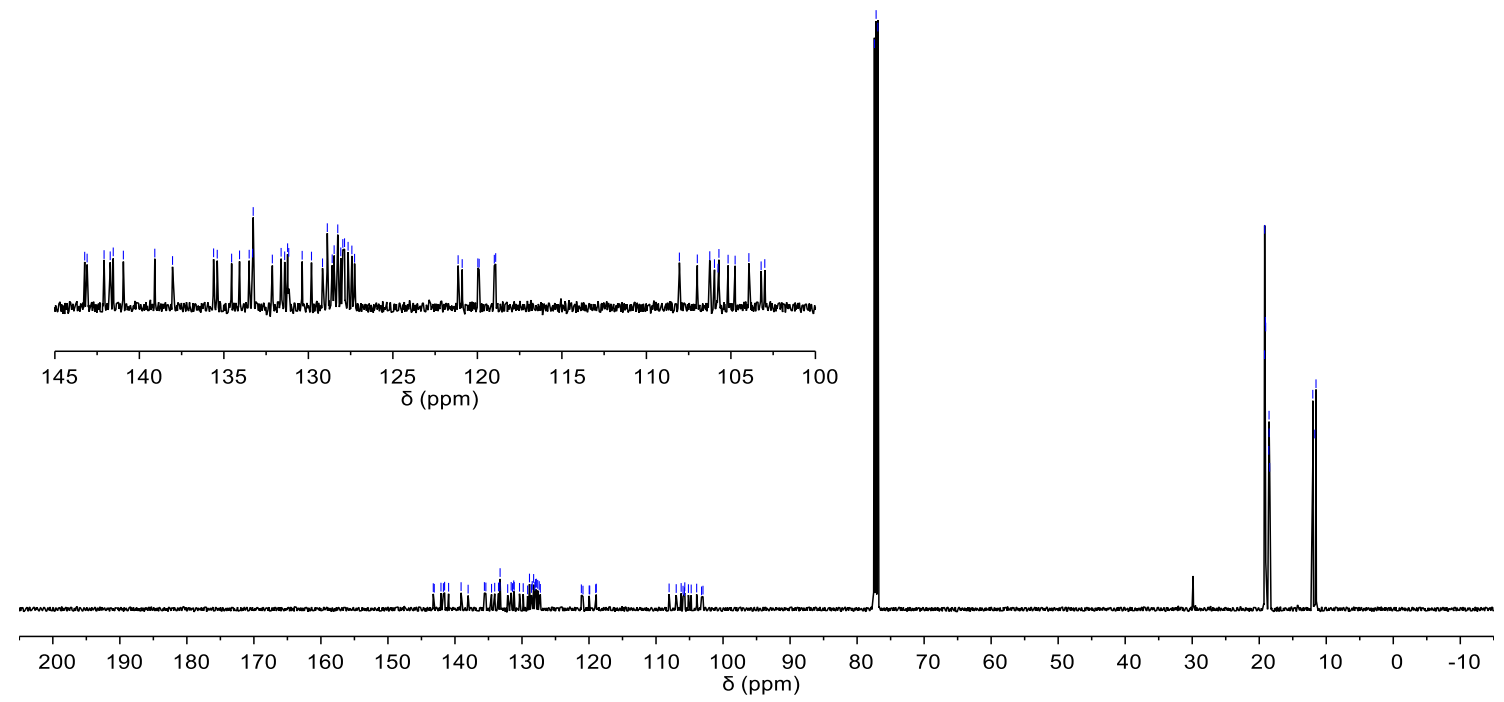

Figure S3-12. ${ }^{13} \mathrm{C}$ NMR spectrum of 2 in $\mathrm{CDCl}_{3}$ at room temperature $(500 \mathrm{MHz})$. 


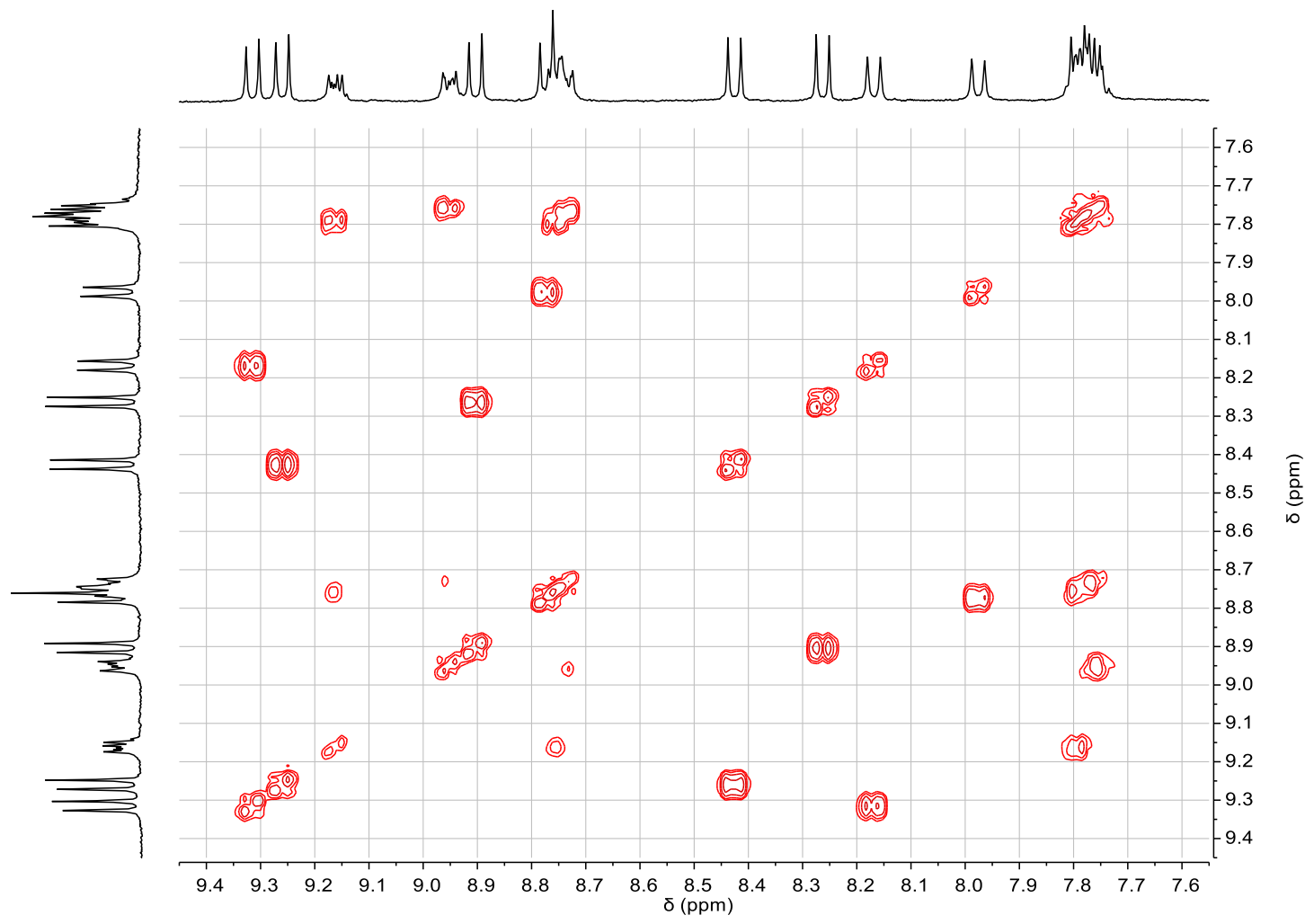

Figure S3-13. ${ }^{1} \mathrm{H}-{ }^{1} \mathrm{H}$ COSY chart of 2 in $\mathrm{CDCl}_{3}$ at room temperature $(500 \mathrm{MHz})$. 


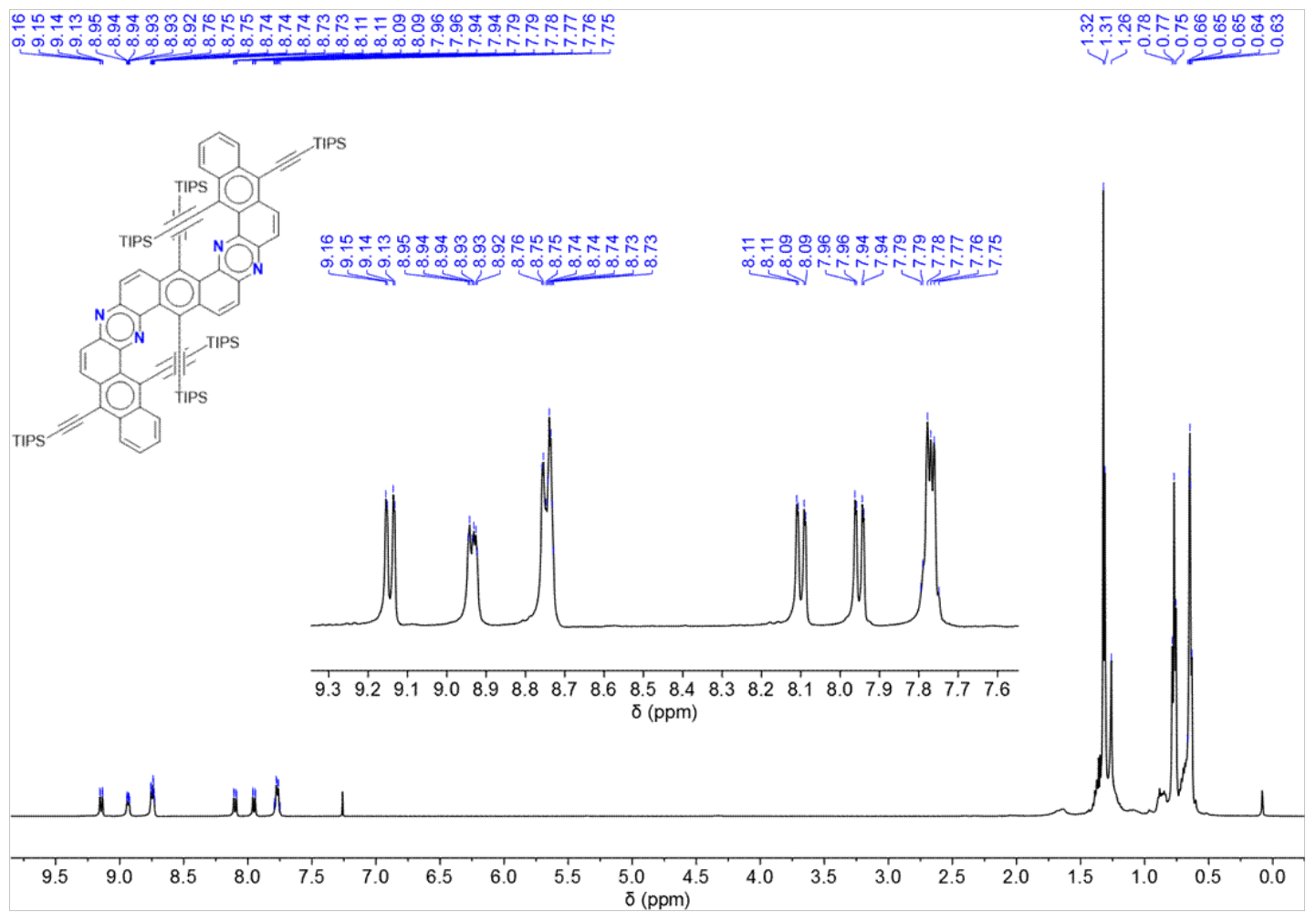

Figure S3-14. ${ }^{1} \mathrm{H}$ NMR spectrum of 3 in $\mathrm{CDCl}_{3}$ at room temperature $(500 \mathrm{MHz})$. 


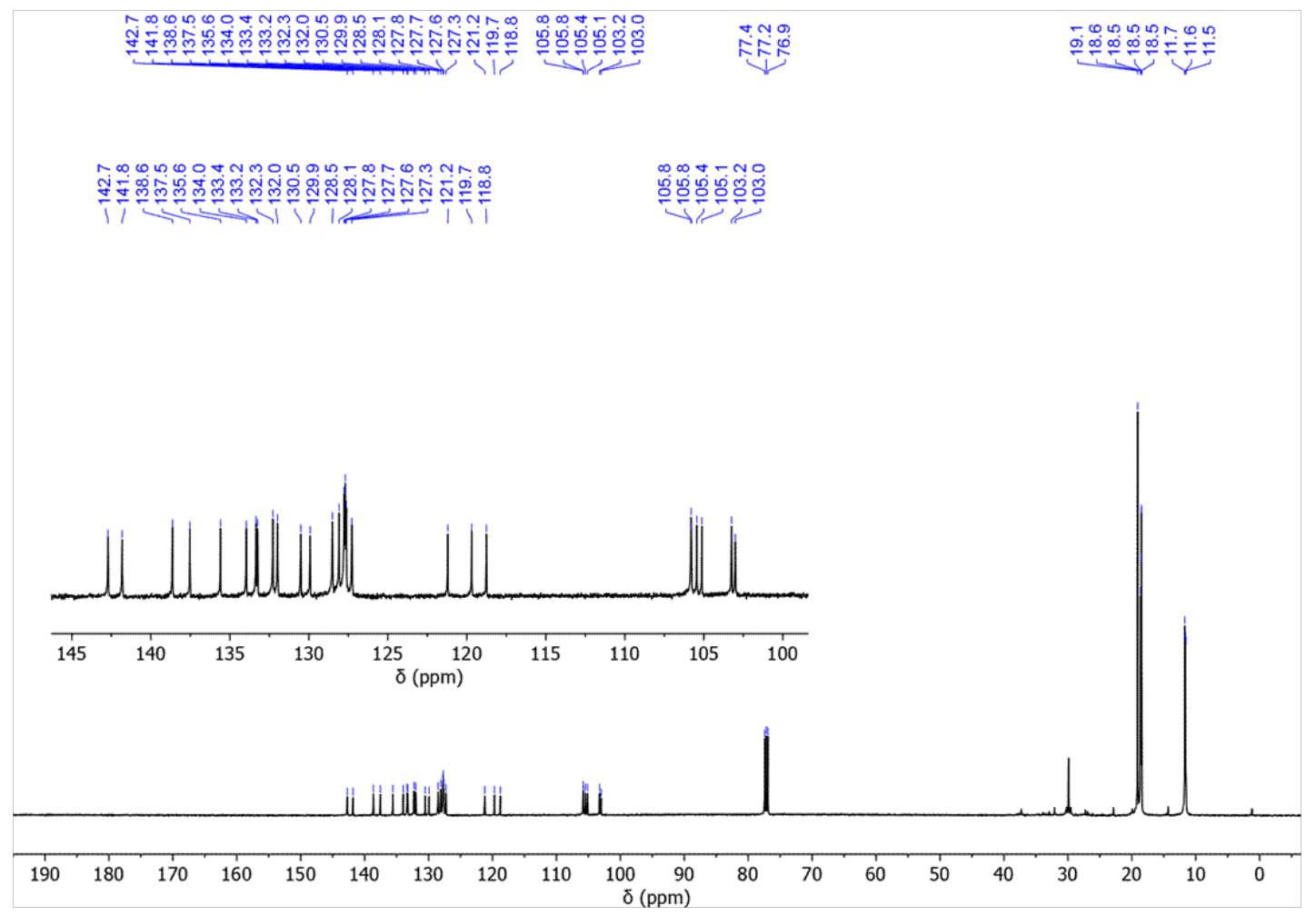

Figure S3-15. ${ }^{13} \mathrm{C}$ NMR spectrum of 3 in $\mathrm{CDCl}_{3}$ at room temperature $(500 \mathrm{MHz})$. 


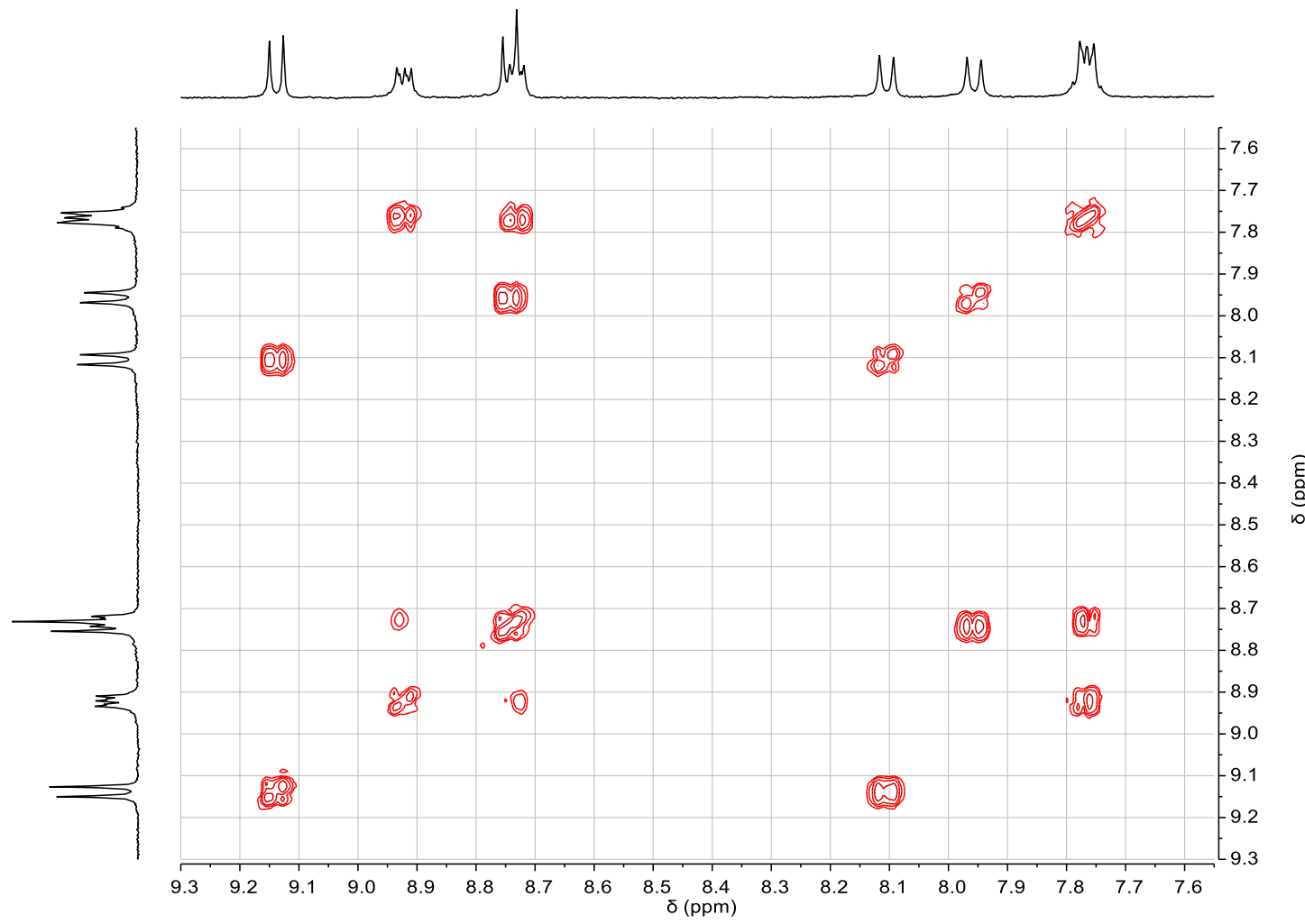

Figure S3-16. ${ }^{1} \mathrm{H}-{ }^{1} \mathrm{H}$ COSY chart of 3 in $\mathrm{CDCl}_{3}$ at room temperature $(500 \mathrm{MHz})$. 


\section{Mass Spectra}

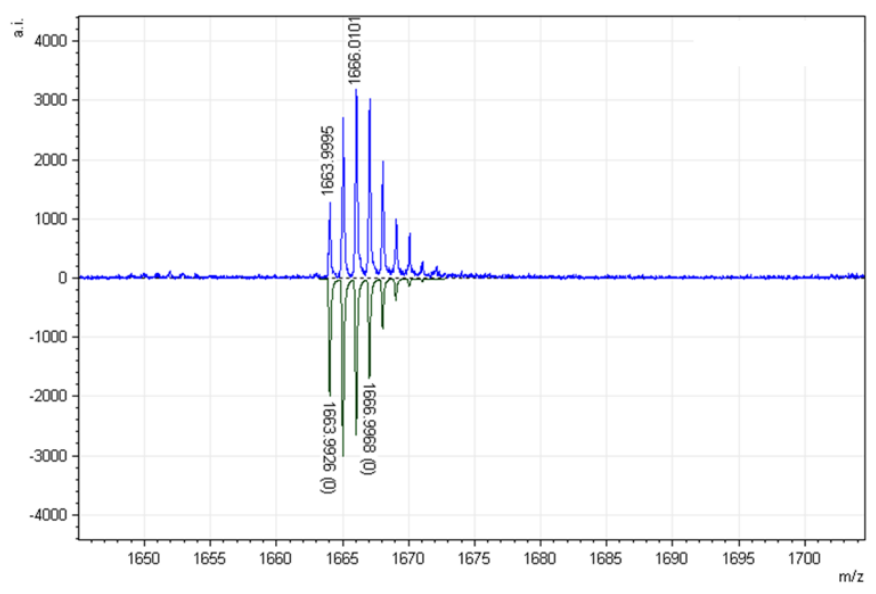

Figure S4-1. MALDI-TOF-MS of 1 (Top; observed. Bottom; calculated).

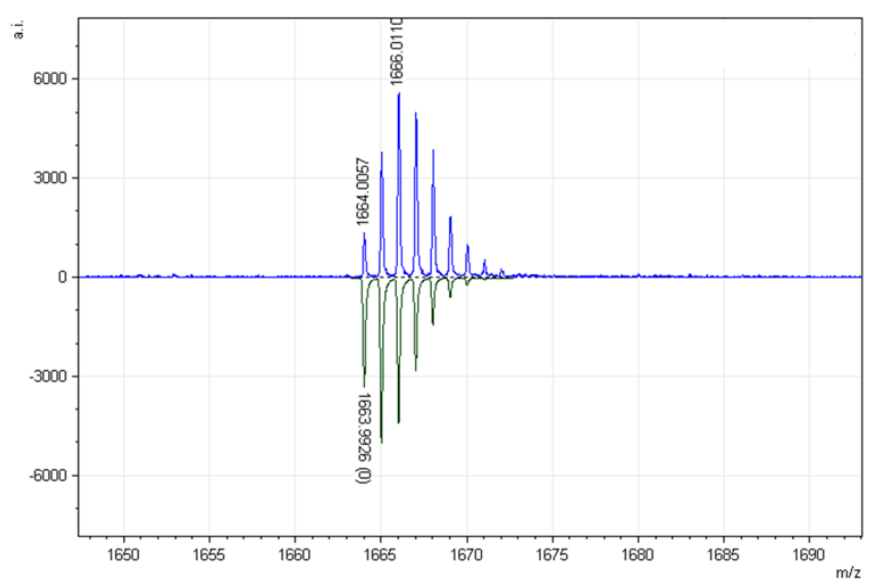

Figure S4-2. MALDI-TOF-MS of 2 (Top; observed. Bottom; calculated).

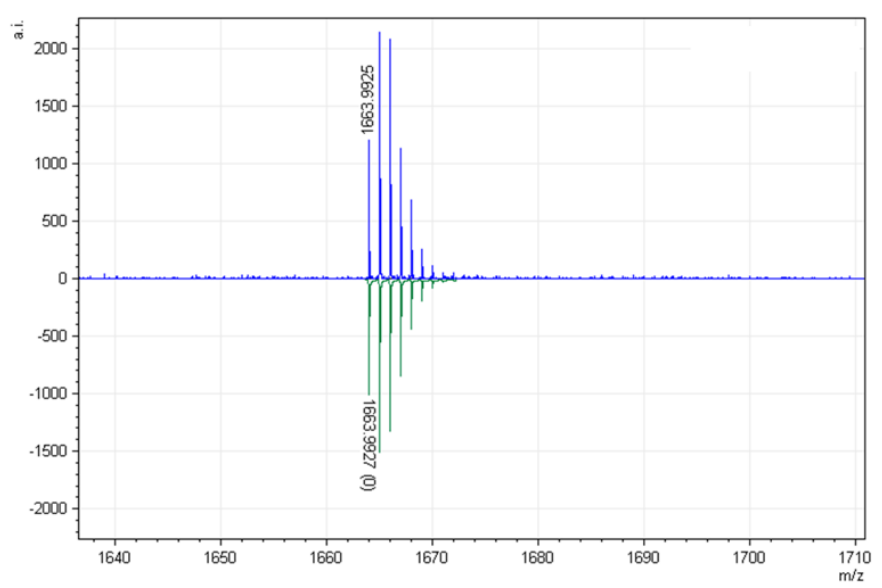

Figure S4-3. MALDI-TOF-MS of 3 (Top; observed. Bottom; calculated). 


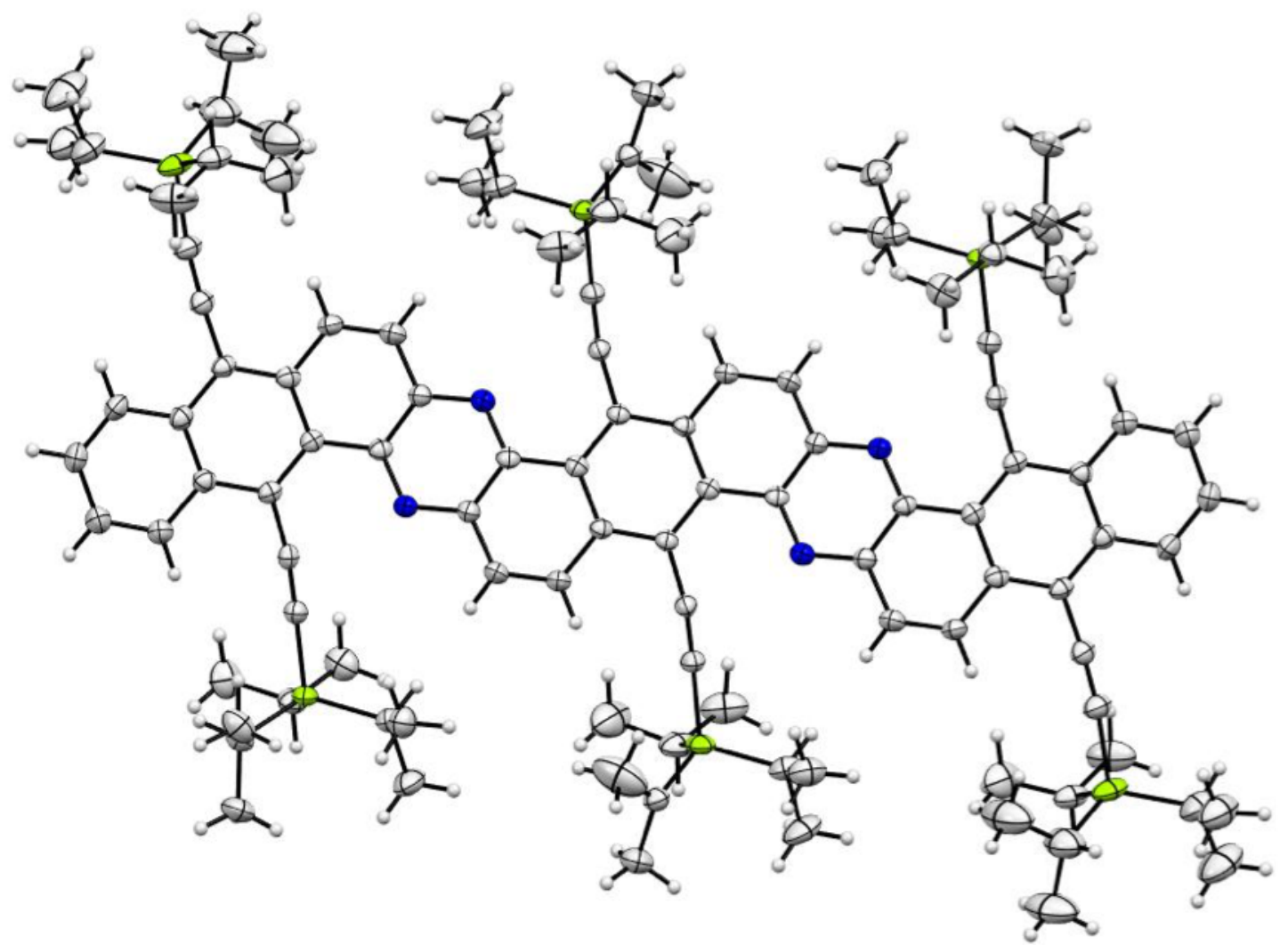

Figure S5-1. X-ray crystal structure of 1 (top view). Thermal ellipsoids were scaled to 50\% probability. (N: blue; Si: green).

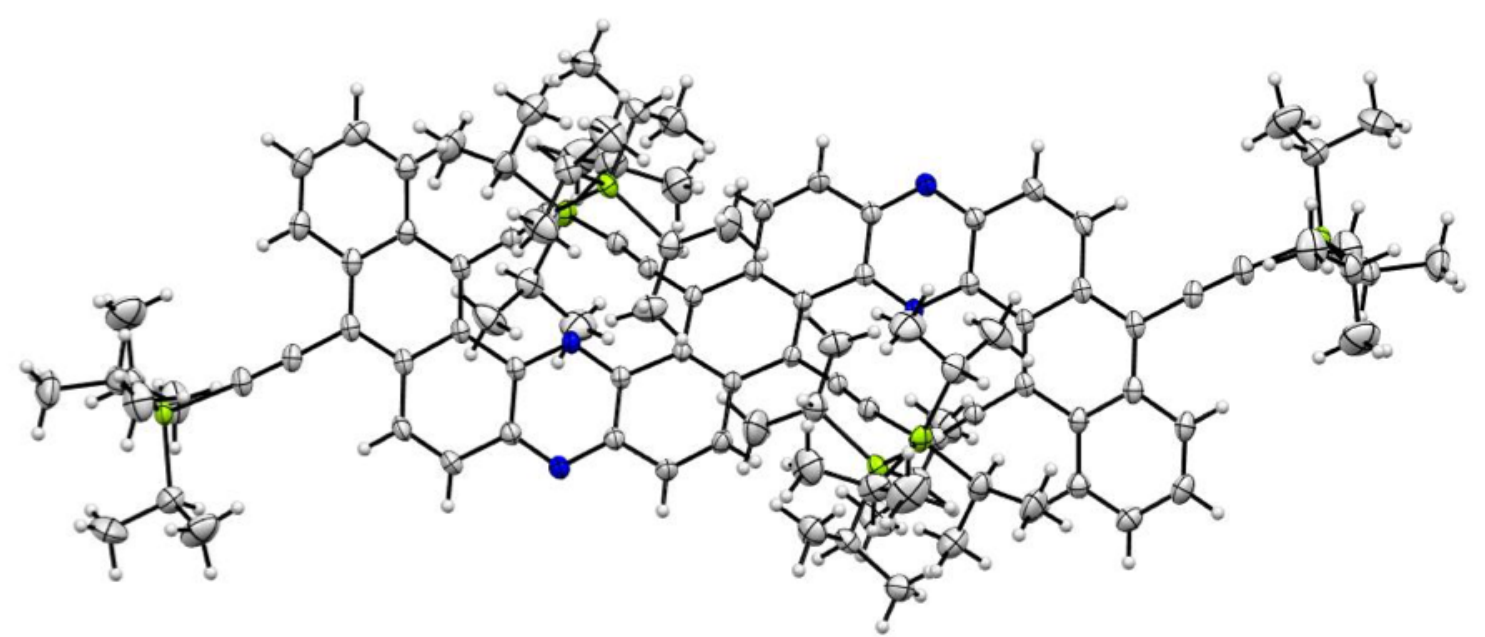

Figure S5-2. X-ray crystal structure of 3 (top view). Thermal ellipsoids were scaled to 50\% probability. (N: blue; Si: green). 
Table S5-1. Crystal data and structure refinements for $\mathbf{1}$ and $\mathbf{3 .}$

\begin{tabular}{|c|c|c|}
\hline Compound & 1 & 3 \\
\hline Empirical Formula & $\mathrm{C}_{108} \mathrm{H}_{140} \mathrm{~N}_{4} \mathrm{Si}_{6}$ & $\mathrm{C}_{218} \mathrm{H}_{28} \mathrm{Cl}_{3} \mathrm{~N}_{8} \mathrm{Si}_{12}$ \\
\hline$M_{W}$ & 1662.77 & 3464.98 \\
\hline Crystal System & monoclinic & monoclinic \\
\hline Space Group & $\mathrm{I} 2 / \mathrm{a}$ & $\mathrm{I} 2 / \mathrm{a}$ \\
\hline$a[\AA]$ & $14.9413(6)$ & $24.6776(2)$ \\
\hline$b[\AA]$ & $14.8293(6)$ & $15.92020(12)$ \\
\hline$c[\AA]$ & $46.216(2)$ & $27.7986(2)$ \\
\hline$\alpha[\operatorname{deg}]$ & 90 & 90 \\
\hline$\beta[\operatorname{deg}]$ & $95.536(4)$ & $103.5837(9)$ \\
\hline$\gamma[\operatorname{deg}]$ & 90 & 90 \\
\hline Volume $\left[\AA^{3}\right]$ & $10192.3(8)$ & 10615.79(16) \\
\hline$Z$ & 4 & 2 \\
\hline Density $\left[\mathrm{mg} / \mathrm{m}^{3}\right]$ & 1.084 & 1.084 \\
\hline Completeness & 0.999 & 0.998 \\
\hline Goodness-of-fit & 1.026 & 1.049 \\
\hline$R_{1}[I>2 \sigma(I)]$ & 0.0620 & 0.0593 \\
\hline$w R_{2}[I>2 \sigma(I)]$ & 0.1620 & 0.1734 \\
\hline$R_{1}$ (all data) & 0.0956 & 0.0674 \\
\hline$w R_{2}$ (all data) & 0.1877 & 0.1815 \\
\hline $\mathrm{CCDC}$ & 1978607 & 1978608 \\
\hline
\end{tabular}




\section{References}

[S1] H. S. Huang, T. C. Chen, R. H. Chen, K. F. Huang, F. C. Huang, J. R. Jhan, C. L. Chen, C. C. Lee, Y. Lo and J. J. Lin, Bioorg. Med. Chem. 2009, 17, 7418.

[S2] J. H. Park, D. S. Chung, J. W. Park, T. Ahn, H. Kong, Y. K. Jung, J. Lee, M. H. Yi, C. E. Park, S. K. Kwon and H. K. Shim, Org. Lett. 2007, 9, 2573.

[S3] S. Izakura, W. Gu, R. Nishikubo, A. Saeki, J. Phys. Chem. C 2018, 122, 14425.

[S4] Gaussian 09, Revision A.03, M. J. Frisch, G. W. Trucks, H. B. Schlegel, G. E. Scuseria, M. A. Robb, J. R. Cheeseman, G. Scalmani, V. Barone, G. A. Petersson, H. Nakatsuji, X. Li, M. Caricato, A. Marenich, J. Bloino, B. G. Janesko, R. Gomperts, B. Mennucci, H. P. Hratchian, J. V. Ortiz, A. F. Izmaylov, J. L. Sonnenberg, D. Williams-Young, F. Ding, F. Lipparini, F. Egidi, J. Goings, B. Peng, A. Petrone, T. Henderson, D. Ranasinghe, V. G. Zakrzewski, J. Gao, N. Rega, G. Zheng, W. Liang, M. Hada, M. Ehara, K. Toyota, R. Fukuda, J. Hasegawa, M. Ishida, T. Nakajima, Y. Honda, O. Kitao, H. Nakai, T. Vreven, K. Throssell, J. A. Montgomery, Jr., J. E. Peralta, F. Ogliaro, M. Bearpark, J. J. Heyd, E. Brothers, K. N. Kudin, V. N. Staroverov, T. Keith, R. Kobayashi, J. Normand, K. Raghavachari, A. Rendell, J. C. Burant, S. S. Iyengar, J. Tomasi, M. Cossi, J. M. Millam, M. Klene, C. Adamo, R. Cammi, J. W. Ochterski, R. L. Martin, K. Morokuma, O. Farkas, J. B. Foresman, D. J. Fox, Gaussian, Inc., Wallingford CT, 2009.

[S5] C. Bannwarth, S. Ehlert, S. Grimme J. Chem. Theory Comput. 2019, 15, 1652. 